\title{
Computational Analysis of a Wing Designed for the X-57 Distributed Electric Propulsion Aircraft
}

\author{
Karen A. Deere*, Jeffrey K. Viken†, Sally A. Viken*, Melissa B. Carterł \\ NASA Langley Research Center, Hampton, VA 23681, USA \\ Michael R. Wiese§ and Norma Farr** \\ Craig Technologies, Hampton, VA 23681, USA
}

\begin{abstract}
A computational study of the wing for the distributed electric propulsion X-57 Maxwell airplane configuration at cruise and takeoff/landing conditions was completed. Two unstructured-mesh, Navier-Stokes computational fluid dynamics methods, FUN3D and USM3D, were used to predict the wing performance. The goal of the X-57 wing and distributed electric propulsion system design was to meet or exceed the required lift coefficient 3.95 for a stall speed of 58 knots, with a cruise speed of 150 knots at an altitude of 8,000 ft. The X-57 Maxwell airplane was designed with a small, high aspect ratio cruise wing that was designed for a high cruise lift coefficient (0.75) at angle of attack of $0^{\circ}$. The cruise propulsors at the wingtip rotate counter to the wingtip vortex and reduce induced drag by 7.5 percent at an angle of attack of $0.6^{\circ}$. The unblown maximum lift coefficient of the high-lift wing (with the $30^{\circ}$ flap setting) is 2.439 . The stall speed goal performance metric was confirmed with a blown wing computed effective lift coefficient of 4.202. The lift augmentation from the high-lift, distributed electric propulsion system is 1.7. The predicted cruise wing drag coefficient of 0.02191 is 0.00076 above the drag allotted for the wing in the original estimate. However, the predicted drag overage for the wing would only use 10.1 percent of the original estimated drag margin, which is 0.00749 .
\end{abstract}

\section{Nomenclature}

\begin{tabular}{|c|c|c|c|}
\hline$C_{D}$ & drag coefficient & $V_{t, \text { ratio }}$ & ratio of tip speed to freestream velocity \\
\hline$C_{D, H L N}$ & drag coefficient, high-lift nacelles contribution & $\mathrm{W}$ & aircraft weight, lb \\
\hline$C_{D, p y l o n s}$ & drag coefficient, pylons contribution & $\mathrm{y}$ & axis along the wing span, in. \\
\hline$C_{D, T N}$ & drag coefficient, wingtip nacelles contribution & $y^{+}$ & nondimensional first node height in boundary layer \\
\hline $\begin{array}{l}C_{D, w i n g} \\
C_{f}\end{array}$ & $\begin{array}{l}\text { drag coefficient, wing contribution } \\
\text { skin friction coefficient }\end{array}$ & $y_{C C}^{+}$ & nondimensional first cell centroid height in boundary layer \\
\hline$C_{L}$ & lift coefficient & Symbols & \\
\hline$c l$ & sectional lift coefficient & $\alpha$ & angle of attack, degrees \\
\hline$C_{L, e f f}$ & effective lift coefficient: $C_{L}+C_{L, p r o p}$ & $\Delta$ & delta \\
\hline$C_{L, \max }$ & maximum lift coefficient & $\rho$ & density \\
\hline$C_{L, p r o p}$ & $\begin{array}{l}\text { lift coefficient from the contribution of } \\
\text { propeller thrust in lift direction }\end{array}$ & $\begin{array}{l}\text { Acronyms } \\
\text { BSL }\end{array}$ & Menter $k-\omega$ basic turbulence model \\
\hline$C_{m}$ & pitching moment coefficient & CFL & pseudo time advancement Courant-Friedrichs-Lewy \\
\hline$C_{p}$ & pressure coefficient & DEP & distributed electric propulsion \\
\hline$C_{r e f}$ & reference chord, in. & HLN & high-lift nacelles, including pylons \\
\hline$C_{T}$ & thrust coefficient & $\mathrm{HP}$ & horse power \\
\hline$C_{Q}$ & torque coefficient & KCAS & knots calibrated airspeed \\
\hline $\mathrm{D}$ & drag force & KEAS & knots equivalent airspeed \\
\hline $\mathrm{d}$ & propeller diameter, $\mathrm{ft}$. & KTAS & knots true airspeed \\
\hline $\mathrm{h}$ & altitude, $\mathrm{ft}$. & LM & Langtry-Menter transition model \\
\hline$K_{T}$ & normalized thrust coefficient & $\mathrm{mph}$ & miles per hour \\
\hline$K_{Q}$ & normalized torque coefficient & QCR & quadratic constitutive relation \\
\hline$M$ & Mach number & RPM & revolutions per minute \\
\hline $\mathrm{P}$ & pressure, $\mathrm{lbf} / \mathrm{in}^{2}$ & SA & Spalart-Almaras one equation turbulence model \\
\hline q & dynamic pressure & SARC & SA rotation and curvature correction \\
\hline $\begin{array}{l}R e \\
\mathrm{~S}\end{array}$ & $\begin{array}{l}\text { Reynolds number based on } C_{r e f} \\
\text { wing reference area, } \mathrm{ft}^{2}\end{array}$ & SCEPTOR & $\begin{array}{l}\text { Scalable Convergent Electric Propulsion Technology and } \\
\text { Operations Research }\end{array}$ \\
\hline $\mathrm{T}$ & temperature, ${ }^{\circ} \mathrm{F}$ & SST & Menter's Shear Stress Transport model \\
\hline $\mathrm{V}$ & freestream velocity, $\mathrm{ft} / \mathrm{sec}$ & $\mathrm{TN}$ & wingtip nacelles \\
\hline
\end{tabular}

\footnotetext{
*Aerospace Engineer, Configuration Aerodynamics Branch, Mail Stop 499, AIAA Senior Member. $\dagger$ Aerospace Engineer, Aeronautics Systems Analysis Branch, Mail Stop 442, AIAA Senior Member.

* Aerospace Engineer, Configuration Aerodynamics Branch, Mail Stop 499, AIAA Associate Fellow.

$\S$ Senior Researcher, GEOLAB, Mail Stop 128.

*** Technical Group Lead, GEOLAB, Mail Stop 128.
} 


\section{Introduction}

The NASA New Aviation Horizons Initiative has a goal of green aviation to alleviate the negative impacts associated with the expected doubling in growth of passenger trips per year from now to 2035, and to take advantage of the economic potential of being aeronautical leaders in the future aviation growth [1]. Clean, quiet, and even supersonic airplanes are planned within the NASA X-plane research approach to improve energy efficiency, and develop technologies and new propulsion systems that will enable innovative airplane designs. The X-57 Maxwell, or Scalable Convergent Electric Propulsion Technology and Operations Research (SCEPTOR) airplane is one of several airplanes worthy of the X-plane status. One goal of the all-electric X-57 Maxwell technology demonstrator is to prove that significantly reducing wing area (to improve cruise efficiency) can be done without compromising takeoff and landing performance. This is accomplished by application of distributed electric propulsion (DEP) to effectively blow a higher " $q$ " (dynamic pressure) over the wing and flap during takeoff and landing conditions.

The new DEP wing system for the X-57 airplane demonstrator will be installed on a Tecnam P2006T aircraft (fig. 1) by removing the original wing and installing the cruise-optimized DEP wing (fig. 2). The main performance goals are a 58 knots equivalent airspeed (KEAS) stall speed (scaled from the original P2006T gross weight and stall performance), at 3,000 lb gross weight equating to a $C_{L}=3.95$, while achieving a cruise speed of 150 knots true airspeed (KTAS) at 8,000 feet. It is projected that the all-electric X-57 Maxwell airplane will achieve 5 times lower energy use than the original P2006T. The efficiency gains will be accomplished with aerodynamic improvements and by the increased propulsion system efficiency of the electric motor/battery system. The sizing design study of the wing presented in Reference 2 resulted in a wing design with a wing loading of $45 \mathrm{lb} / \mathrm{ft}^{2}$, a wing area of $66.67 \mathrm{ft}^{2}$, an aspect ratio of 15 , and a cruise $C_{L}=$ 0.75. The higher aspect ratio for the new wing is needed to minimize induced drag at cruise, since the new wing's cruise lift coefficient is much higher than the original P2006T. The original P2006T has a wing loading of $16.365 \mathrm{lb} / \mathrm{ft}^{2}$, a wing area of $158.88 \mathrm{ft}^{2}$, an aspect ratio of 8.8 , and a cruise $C_{L}=0.275$. The specially designed X-57 airfoil is tailored for a cruise lift coefficient of 0.90 and incorporates a $25 \%$ chord flap. The flap design uses a single-pivot displaced hinge with a $30^{\circ}$ maximum deflection.

\section{Configurations}

The configurations analyzed in this computational study of the wing for the DEP X-57 Maxwell airplane were the cruise wing and the high-lift wing, which has a $30^{\circ}$ flap setting (figure 3 ). The X-57 Maxwell wing has been through several design improvement revisions and the configurations that are presented in this paper are the 4.1 design revision. The X-57 Maxwell airplane has 12 high-lift propellers mounted on nacelles upstream of the wing leading edge that are positioned in an alternating fore- and aftstaggered pattern. The high-lift propellers are designed to fold smoothly onto the nacelle for the cruise configuration (fig. 3(a)), which is referred to as the cruise wing in this paper. The high-lift propellers (not shown) are positioned on the nacelles in an alternating fore- and aft-staggered pattern for the high-lift blown wing $\left(30^{\circ}\right.$ flap shown in red in fig. 3(b)). The cruise wing without HLN (fig. 3(c)) and the high-lift wing without HLN (fig. 3(d)), were also analyzed to investigate the impact of the pylon and nacelle geometry on wing performance (lift coefficient discussed in this paper). The fuselage and tail were not included in this study but will be included in future computational fluid dynamics (CFD) methods analysis of the X-57 airplane.

\section{High-Fidelity Distributed Propulsion Analysis Tools}

Two unstructured-mesh, Navier-Stokes CFD methods were used to define the wing performance, FUN3D [3] and USM3D [4, 5]. Additionally, wing performance was compared with other computational methods (OVERFLOW and STARCCM+) in reference 6, with the goal to characterize and provide further confidence in the computational results.

FUN3D is a node-based, finite-volume discretization, Reynolds-averaged Navier-Stokes flow solver. Fully turbulent predictions were computed with FUN3D using the Spalart-Allmaras one-equation turbulence model with rotation and curvature correction (SARC) [7] and the quadratic constitutive relation (QCR) [8] of Spalart. Additionally, some cases were also computed with two-equation turbulence models; Menter $k$ - $\omega$ basic (BSL) and Shear-Stress Transport (SST) [9]. For this work, FUN3D was the primary method used to define $C_{L, \max }$ for the cruise wing and the high-lift wing with a $30^{\circ}$ flap. All of the FUN3D simulations for this study used an actuator disk representation for the high-lift propellers, with thrust and torque coefficient 
data being inputs to the solution. The thrust and torque coefficient data were derived from the XROTOR [10] blade element momentum analyses.

USM3D is a cell-centered, finite-volume discretization, Reynolds-averaged Navier-Stokes flow solver. Three turbulence models were used in this study; SA [7-8], SST [9], and the Langtry-Menter (LM) transition model [11-12]. In order to understand the drag benefit that might be possible with laminar flow, the USM3D flow solver with the LM transition model was used for predicting transitional flow along the wing. Fully turbulent solutions were also computed with the SA and SST turbulence models, using both USM3D and FUN3D, to provide a baseline for comparison to the laminar flow prediction. In this paper, USM3D was not used for powered solutions.

\section{A. Grid Generation}

GridTool/VGRID [13] software was used to generate the meshes for FUN3D and USM3D simulations. GridTool is used to take a supplied geometry file and create the necessary points, curves, patches and grid topology (sources) to define the surface for grid generation. VGRID is a tetrahedral unstructured grid program that can either be run interactively or in a batch mode with grid spacing corresponding to the strength of user-defined sources placed in the domain. The advancing layers method [14] is used to generate the boundary layer and the advancing front is used to generate the farfield tetrahedral mesh. POSTGRID is used for additional post-processing, to close any open pockets that do not have cells and to improve the grid quality.

An unstructured, mixed element mesh was used for the FUN3D simulations. The mixed element mesh had prisms in the boundary layer and tetrahedral cells in the farfield, with pyramids to transition between the boundary layer and farfield cells. Semispan wings were used in the computational model since all calculations were computed at $0^{\circ}$ angle of sideslip and little lateral variation was expected. A full span solution was computed for the blown, high-lift wing $\left(30^{\circ}\right.$ flap) with high-lift nacelles at $\alpha=0^{\circ}$. The differences between the full span and semispan configurations for lift, drag, and pitching moment coefficient were $0.2 \%, 0.8 \%$ and $0.1 \%$, respectively. These small differences between the solutions confirmed the approach of using a semispan mesh.

For all grids, a flat-plate, turbulent boundary layer calculator was used with the reference chord length, a Reynolds number based on reference chord length, the intended $y^{+}$, and an intended number of layers of cells within the boundary layer, to determine the first node height and expansion rate of the grid for input to VGRID. Previous results from the LEAPTech wing (not shown in this paper) showed that using an intended $y^{+}=0.67$ for a medium mesh had solution $y^{+}$values up to 2 for the blown, high-lift wing solutions, even though the solution $y^{+}$were less than 1 for the unblown wing solutions. Values of solution $y^{+}$that are less than 1 are recommended to adequately model the boundary layer flow.

For all grids, the farfield boundaries were extended to approximately 100 chord lengths away from the wing and the reference chord length was $C_{r e f}=25.56 \mathrm{in}$.

For the FUN3D code, the semispan mesh of the cruise wing with wingtip nacelles had 43.9 million mesh points and the semispan mesh for the cruise wing with high-lift and wingtip nacelles had 47.9 million mesh points. As recommended in reference 15, both meshes were generated with an intended $y^{+}=0.3$ for an extra fine mesh, and 32 grid layers were specified within the boundary layer. The corresponding VGRID spacing for the first node height was $6.3 \mathrm{e}-5$ in. as determined by the boundary layer calculator for the cruise mesh at $R e=2.83$ million, and $150 \mathrm{KTAS}$.

The same grid created for the cruise wing with high-lift and wingtip nacelles was used for USM3D. The number of cells are important for USM3D since it is a cell-centered code, and the 47.9 million mesh points grid had 282.5 million cells. This means that for the same grid USM3D has 6 times more resolution than FUN3D. Consequently, a smaller grid could be used for USM3D, however, since time was limited, the same grid was used and another grid with similar resolution as the FUN3D solution was not made. The advancing layers method forms prismatic layers that are divided into three tetrahedral cells. The distance from the surface to the centroids of the tetrahedral boundary cells is one-fourth that of the first layer of nodes, resulting in the $y_{C C}^{+}=0.25 \cdot y^{+}[16]$. Therefore, the FUN3D mesh used for running the USM3D code has the $y_{C C}^{+}=0.075$.

The FUN3D semispan mesh for the high-lift wing ( $30^{\circ}$ flap setting) and tip nacelle had 149 million mesh points. Adding the high-lift nacelles brought the grid to 153 million mesh points. Both meshes were generated with an intended $y^{+}=0.3$ and 32 grid layers within the boundary layer. The corresponding VGRID spacing for the first node height was $1.3 \mathrm{e}-4 \mathrm{in}$. for the high-lift wing mesh at $\operatorname{Re}=1.33$ million, and 
58 KTAS.

No special patching is required within the grid for FUN3D to simulate the propellers, except clustering of cells to resolve the flow. The clustering of cells was achieved using VGRID volume sources during grid generation. Grids for powered runs with the USM3D code do require patches to create the actuator disk, which simulate the propellers, however, powered solutions were not computed with USM3D for this paper.

\section{B. Computational scheme}

The process for running the FUN3D code for all of the cases shown was to start the solutions as steadystate with a local time stepping method. If needed, solutions were switched to time-accurate, global time stepping, to obtain acceptable convergence. In nearly all of the cases with separated flow, which were near the stall condition, the final converged solution was computed with the time-accurate global time stepping method.

Since the USM3D code was run on the cruise wing at cruise conditions where little flow separation was expected, the solutions were obtained using the steady-state, local time stepping method and converged well.

\section{Boundary Conditions and Actuator Disk Modeling}

A symmetry plane boundary condition is used for the semispan grids while the farfield boundaries utilized the Riemann invariants boundary condition. All of the solid surfaces were set with the no-slip boundary condition.

An actuator boundary condition was used to simulate the high-lift (HL) propellers. There are 6 options to loading the rotor in FUN3D but the one implemented for this work was a body force based on the optimal distribution of Goldstein [17] implemented as described by Stern, Kim, and Patel [18]. Inputs for the actuator boundary condition include tip radius (11.34 in.), hub radius (3.06 in.), and the (x, y, z) location of the hub centers for each high-lift propeller. Additionally, the $V t_{\text {ratio }}$, the normalized thrust coefficient and the normalized torque coefficient were required for each propulsor. The $V t_{\text {ratio }}$, as defined by equation 1 was calculated to be equal to 4.5976 . Positive values of $V t_{\text {ratio }}$ results in the propellers on the right wing to rotate in a clockwise direction from the pilot's view, a rotation that opposes the wingtip vortex. The torque and thrust coefficients, equations 2 and 3, respectively, were calculated using $4548 \mathrm{RPM}$, a torque of $15.9 \mathrm{ft}$ $\mathrm{lbf}$, a thrust of $49.7 \mathrm{lbf}$, and the propeller diameter (d) of $1.89 \mathrm{ft}$. The normalized torque coefficient $\left(K_{Q}=\right.$ $0.0125)$ and normalized thrust coefficient $\left(K_{T}=0.0368\right)$ were computed with equations 4 and 5 and used in the actuator boundary condition input file.

$$
\begin{aligned}
& V t_{\text {ratio }}=\left[\pi *\left(\frac{R P M}{60}\right) * d\right] / V \\
& C_{Q}=\text { Torque } /\left[\rho\left(\frac{R P M}{60}\right)^{2} d^{5}\right] \\
& C_{T}=\text { Thrust } /\left[\rho\left(\frac{R P M}{60}\right)^{2} d^{4}\right] \\
& K_{Q}=\frac{8}{\pi^{3}} C_{Q} \\
& K_{T}=\frac{4}{\pi^{3}} C_{T}
\end{aligned}
$$

\section{Flow Conditions}

Computational solutions of the cruise wing were computed at a cruise speed of 150 KTAS and at an altitude of $8,000 \mathrm{ft}$. Computational solutions of the high-lift wing (with a $30^{\circ}$ flap setting) were computed for a landing speed of 58 KTAS at sea level.

\section{E. Convergence}

The criteria used to monitor and determine solution convergence was a drop of at least two orders of magnitude for the flow solution residual. In addition, for an interval of 1,000 iterations, it was required that for steady-state solutions the standard deviation of $C_{L}$ be less than 0.0012 and $C_{D}$ be less than 0.0020 .

The FUN3D steady-state solutions for the cruise wing with tip nacelle all converged to a standard deviation less than 0.0001 for both $C_{L}, C_{D}$, and $C_{m}$. Steady-state cases for the cruise wing with high-lift and 
wingtip nacelles $\left(\alpha<10^{\circ}\right)$ converged to a standard deviation less than $0.0005,0.00006$, and 0.0002 for $C_{L}$, $C_{D}$, and $C_{m}$, respectively.

The USM3D code was run on the cruise wing at an angle of attack of $0.6^{\circ}$. The USM3D SA solution converged with standard deviations of $0.00009,0.000003$, and 0.00002 in $C_{L}, C_{D}$, and $C_{m}$, respectively, over 2000 iterations. The USM3D SST solution converged with standard deviations of $0.00007,0.0000004$, and 0.00003 in $C_{L}, C_{D}$, and $C_{m}$, respectively, over 2000 iterations. The USM3D LM solution converged with standard deviation of $0.00035,0.00003$, and 0.00014 in $C_{L}, C_{D}$, and $C_{m}$, respectively, over 6000 iterations.

\section{Results}

The traditional lift coefficient $\left(C_{L}\right)$ and the effective lift coefficient $\left(C_{L, e f f}\right)$ are discussed throughout the paper. The effective lift coefficient includes the addition of the vectors of propeller thrust and normal force in the lift direction, to the lift coefficient computed from the CFD pressures. The propeller contributions have a small effect at low angles of attack, but can be on the order of $\Delta C_{L}=0.10$ to 0.20 at $\alpha=10^{\circ}$ in the high-lift DEP cases.

A component drag breakdown was conducted in the NASA SCEPTOR DEP demonstrator (X-57 Maxwell) sizing study [1] and the pie chart of the drag elements is presented in Figure 4. The drag components are summed up in Table 1 and the resulting airplane drag coefficient required to meet the cruise speed goal is $C_{D}=0.05423$. Note $C_{D}$ is nondimensionalized with the new X-57 wing area, $\mathrm{S}=66.67 \mathrm{ft}^{2}$. A drag margin of $C_{D}=0.00749$ was built into the airplane drag coefficient required to meet the cruise speed goal, to account for uncertainties in the estimate. The drag margin is about $13.8 \%$ of the total estimated airplane drag. The drag components attributed to the wing are summed up in Table 2 . The drag of the wing (induced + friction + profile + cruise nacelles + high-lift nacelles) should not exceed $C_{D}=0.02115$.

The FUN3D results of $C_{L}$ and $C_{D}$ for the cruise wing with the high-lift nacelles are shown in Figure 5. The unpowered cruise wing achieves $C_{L, \max }=1.7$ at $\alpha=16^{\circ}$ (fig. 5(a)). A high lift coefficient is needed at the cruise condition because the DEP wing is designed to be small with a high aspect ratio for efficiency. At an angle of attack of $\alpha=0.6^{\circ}$, the unpowered wing has a lift coefficient $C_{L}=0.756$. When cruise power is included in the solution, the lift coefficient increases to $C_{L}=0.780$. The cruise propulsors at the wingtip rotate counter to the wingtip vortex and do provide some induced drag reduction (fig. 5(b)). The cruise propulsors reduce drag by 16 counts at $\alpha=-2^{\circ}$, by 23 counts at $0^{\circ}$ and $2^{\circ}$ angles of attack, and by 24 counts at $0.6^{\circ}$ angle of attack. At $\alpha=0.6^{\circ}$, the 24-count drag reduction from the wingtip propulsor accounts for a total wing drag reduction of 7.5 percent. The drag coefficients for these fully turbulent flow solutions at $\alpha=$ $0.6^{\circ}$ is $C_{D}=0.03254$ for the unpowered case and $C_{D}=0.0301$ for the cruise power case because of the induced drag reduction. The design target wing drag coefficient needed for the cruise condition is $C_{D}=$ 0.02115. The CFD turbulent drag coefficient does include the drag on the wing planform that is inside the fuselage. It also does not account for achievement of laminar flow on the wing. These corrections are explained as follows. The CFD semispan grid extends from the fuselage centerline $(y=0.0 \mathrm{in}$.) to the wingtip, however, the half-width of the fuselage extends to the wing span location of $y=24.0 \mathrm{in}$. The portion of the new DEP wing that contributes to aircraft drag will be outside of station $y=24 \mathrm{in}$. The spanwise section drag coefficient $\left(c_{d}\right)$, from the cruise wing CFD solution, was first integrated from the centerline to the wingtip. Then the spanwise section drag coefficient $\left(c_{d}\right)$ was integrated from wing station $\mathrm{y}$ $=24$ in. to the wingtip. The difference in the two totals of the drag coefficient, $\Delta C_{D}=-0.00480$, is the drag computed on the wing planform that is inside the fuselage. This yields a fully turbulent, wing drag coefficient that contributes to aircraft drag of $C_{D, y>24}=0.03010-0.00480=0.02530$.

However, the drag breakdown of the performance sizing assessment assumed that some laminar flow would be achieved on the wing. An analysis was initiated to determine the drag savings due to laminar flow on the wing that might be expected in flight on the X-57 airplane, compared to the fully turbulent predictions from FUN3D. The coauthors were unable to get the FUN3D turbulence model with transition to work, using several grids made with VGRID, POINTWISE and GridEX. In order to understand the drag benefit of laminar flow that may be present at cruise, a grid of the cruise wing configuration with high-lift nacelles was run with the USM3D flow solver with several turbulence models and the LM transition model. Two turbulence models were run with USM3D as a comparison for the transition model approach and as a check against the existing FUN3D results. The analysis at $\alpha=0.6^{\circ}$ was for the unpowered cruise airspeed of 150 KTAS, $\mathrm{T}=30.5^{\circ} \mathrm{F}, \mathrm{h}=8000 \mathrm{ft}$, and $R e=2.83$ million. Figure 6 shows the skin friction coefficient $\left(C_{f}\right)$ on the upper and lower surfaces of the wing for the cases analyzed. Figure 6(a) shows the extent of the laminar 
flow predicted with USM3D LM, with low values of $C_{f}$ to approximately 70 percent chord on the upper surface and 60 percent chord on the lower surface, where $C_{f}$ rises to values around 0.005 on the upper surface and 0.003 on the lower surface, as the flow transitions to fully turbulent flow. In contrast, the fully turbulent flow cases (figs. 6(b) to 6(e)) have high $C_{f}$ values near 0.005 to approximately 70 percent chord and the contours are relatively similar between the solutions on the upper surface. However, there are more differences in $C_{f}$ on the lower surface between the fully turbulent cases, with similar contours for the FUN3D solutions, while USM3D predicts higher $C_{f}$ values for SA than FUN3D, and even higher values of $C_{f}$ for SST than SA. At this angle of attack $\alpha=0.6^{\circ}$, the lower surface flow is more influenced by the flow around the pylons and nacelles than the upper surface. Table 3 shows the total drag coefficients and the contributions of the wing, wingtip nacelles, high-lift nacelles and pylons to the total drag for the fully turbulent and transitional flow solutions from FUN3D and USM3D. The total drag coefficient for the fully turbulent models all vary between $C_{D}=0.03254$ and $C_{D}=0.03557$. The drag coefficient of USM3D with the LM transition turbulence model is lower, $C_{D}=0.02938$, with laminar flow on the wing. The LM transition turbulence model does predict laminar flow on the high-lift nacelles as well. However, because of the intended folding propeller installation, practical laminar flow is not expected on the HLN. Therefore, when only the wing drag is considered, and the same code (USM3D) is compared to reduce uncertainty, then the resulting drag reduction due to laminar flow achieved on the base wing planform is a drag reduction of $\Delta C_{D}=-0.00397$. This drag reduction with laminar flow is compared to the fully turbulent result from the SST turbulence model as the basis for comparison. The LM transition model is highly validated against the SST turbulence model [12, 19-20].

Note the computed benefit of laminar flow, $\Delta C_{D}=-0.00397$, includes the wing from the centerline to the wingtip (CFD grid). However, as stated before, the wing planform inside of fuselage station $\mathrm{y}=24$ " is within the fuselage and does not contribute to the aircraft drag. The ratio of the wing planform area from the wing centerline to station $y=24$ in., to the total wing area is 0.146 . Therefore, if we only count the drag benefit of laminar flow on the wing outside of the fuselage, then laminar flow drag reduction is calculated as $\Delta C_{D, \text { laminar } y>24}=-0.00397 *(1-0.146)=-0.00339$. The final computed wing drag coefficient is $C_{D, \text { wing }}=$ $C_{D, y>24}+\Delta C_{D, \text { laminar } y>24}=0.02530-0.00339=0.02191$. The target estimate for the wing drag is $0.02115+$ $0.00749=0.02864$, which includes 74.9 counts of drag as margin. Thus, only $10 \%$ of the originally planned drag margin is required to meet the design cruise goal.

CFD analysis of the high-lift wing are examined next. The traditional and effective lift coefficients for the blown and unblown high-lift wing at a freestream velocity of $58 \mathrm{KTAS}$ are presented in figure 7 . This figure illustrates the increase in lift coefficient over the range of angle of attack from the unblown wing (purple curve), to the blown wing (red curve), as well as the extra benefit to lift coefficient from the thrust vector (blue curve). The unblown $C_{L, \max }$ of the high-lift wing is 2.439 . The blown high-lift wing, with the DEP system operating at $164.4 \mathrm{hp}(13.7 \mathrm{hp} / \mathrm{prop})$, achieves an effective $C_{L, \max }=4.202$ at $\alpha=12^{\circ}$. The traditional, maximum lift coefficient is 3.89 at $\alpha=12^{\circ}$, without the addition of the propeller vectors contributing to lift. At $\alpha=10^{\circ}$, the blown wing $C_{L}$ is 4.15 and the unblown wing $C_{L}$ is 2.4 , a lift augmentation of 1.7. The impact of the lift augmentation is illustrated in figure 8 , a comparison of the spanloading between the unblown and blown high-lift wing at $58 \mathrm{KTAS}$ and $\alpha=10^{\circ}$. The pink vertical lines are placed at the propeller tips to represent the propeller diameter, and the green vertical lines are positioned at the center of the prop hub. The blue curve (s4.1g4m088a10p0.sect_forces) is the spanwise sectional lift coefficient $\left(c_{l}\right)$ distribution for the unblown high-lift wing with HLN, and the slight jaggedness in the curve at the prop hubs represents the effect adjusting the chord that included the nacelles to a wing chord along the span. The red curve (s4.1g4m088a10p2.sect_forces) for the $c_{l}$ of the blown high-lift wing with HLN is substantially higher than the unblown high-lift wing with the peaks in $c_{l}$ at the prop upwash side of the nacelle. Local spanwise section lift coefficients as high as 4.5 to 5.4 are achieved with the high-lift blowing. It can also be seen that the blowing increases the local section $c_{l}$ outside of the blown region. The lift augmentation due to high-lift blowing is represented by the area between the blue and red curves.

Figure 9 shows the difference between two turbulence models on the computed effective lift coefficient for the blown, high-lift wing. In general, the turbulence models match fairly well through $\alpha=8^{\circ}$, and the BSL model predicts a later stall angle of attack by at least $3^{\circ}$. The BSL two-equation turbulence model also predicts a higher effective lift coefficient $\left(C_{L, \max }=4.444\right)$, at a higher angle of attack $\left(\alpha=14^{\circ}\right)$, than the SARC+QCR turbulence model previously discussed. Although the CFD solutions have different $C_{L, \max }$ predictions, the important take away is that even the conservative estimate is exceeding the design 
$C_{L, \max }$ and predicts that the stall speed goal can be met. The advanced one-equation SARC+QCR turbulence model predicts wing stall after $C_{L, \max }$ at $\alpha=12^{\circ}$, and there is a break in the $C_{L}$ curve at $\alpha=13^{\circ}$ from the loss of lift, due to inboard flow separation. The break in the $C_{L}$ curve occurs at higher angle of attack $\left(\alpha=16^{\circ}\right)$ with the two-equation BSL turbulence model, and the loss of lift is more severe from the effect of both inboard and outboard flow separation. Figure 10 shows skin friction coefficient for $\alpha=13^{\circ}$ (SARC+QCR turbulence model) and $\alpha=16^{\circ}$ (BSL turbulence model) in the $\mathrm{x}$ direction. A cut-off limiting value is specified to remove reversed, separated flow from the view of the wing surface (shown in gray). Both the SARC + QCR and BSL turbulence models predict wide flow separation on the inboard, upper wing surface that extends from the leading edge to the trailing edge. Additionally, the BSL turbulence model has extensive outboard flow separation between the flap and the tip nacelle (aileron region) (fig. 10(b)). Figure 11 shows the span locations (fig. $11(\mathrm{a}))$ and $C_{p}$ cuts of $\mathrm{y}=150 \mathrm{in}$., $160 \mathrm{in.,} 170 \mathrm{in}$., and $180 \mathrm{in}$. on the wing comparing the SARC+QCR $\left(\alpha=13^{\circ}\right)$ and BSL $\left(\alpha=16^{\circ}\right)$ turbulence models at the break in the $C_{L}$ curve. The pressure coefficient distributions are similar between two solutions in the blown-wing region of $y=150$ in. and $\mathrm{y}=160 \mathrm{in}$., but the BSL solution has a higher suction peak on the upper surface leading edge because of the higher angle of attack (figs. 11(b) and 11(c)). The flow separation predicted on the upper surface of the wing is outboard of the blown-wing flow for both turbulence models. For the SARC+QCR turbulence model at $\alpha=13^{\circ}$, the separation upstream of the aileron is almost at a constant chord location between 160 in. $<y<180$ in. At station $y=170$ in., the SARC+QCR separation line is at approximately 68 percent chord (fig. 11(d)) and at station $\mathrm{y}=180 \mathrm{in}$., the flow is again attached to the trailing edge. For the BSL turbulence model at $\alpha=16^{\circ}$, the separation region extends past station $\mathrm{y}=180$ in. (fig. 11(e)) and out to the tip nacelle (fig. 10(b)). The separation location varies with span from 77 percent chord at $y=160$ in. (fig. 11(c)), to 59 percent chord at $\mathrm{y}=170 \mathrm{in}$. (fig. 11(d)), and to 13 percent chord at $\mathrm{y}=180 \mathrm{in}$. (fig. 12(e)). In summary, the maximum lift coefficient is higher, at higher angles of attack for BSL compared to SARC+QCR (fig. 9), but the loss of lift after stall is greater with BSL $\left(\Delta C_{L}=0.34\right)$ due to the addition of massive outboard flow separation added to the inboard flow separation present with SARC+QCR $\left(\Delta C_{L}=0.17\right)$.

As mentioned previously, CFD grids were made for both the cruise and the high-lift wing $\left(30^{\circ}\right.$ flap configuration), with and without the HL nacelles (fig. 3) to determine the impact of the high-lift nacelle geometry on the wing lift and drag. The impacts of the high-lift nacelles on the $C_{L}$ of the unblown wing are shown in figure 12 for FUN3D with the SARC+QCR turbulence model. In general, the nacelles reduce the lift across the range of angle of attack and the lift curve slopes are about the same for both the cruise and the high-lift wing. The unpowered cruise wing with high-lift nacelles has a $\Delta C_{L}$ decrement of 0.10 to 0.15 over the computed angle-of-attack range, with the angle-of-attack at stall being the same for both cases (fig. 12(a)). Similarly, the unpowered high-lift wing with HLN configuration has a $\Delta C_{L}$ decrement of 0.05 to 0.11 (fig. 12(b)) compared to the high-lift wing without HLN. The $C_{L}$ decrement due to HLN diminishes as $C_{L, \max }$ is approached. Figure 12 also confirms the benefit of the flap when comparing the lift coefficients between the unblown cruise and high-lift wings. Figure 13 shows a comparison of the spanloading between the unblown cruise wing with and without HLN for 150 KTAS $\alpha=10^{\circ}$. The smooth blue curve (s4.1g1m233a0p0.sect_forces) is the $c_{l}$ distribution for the cruise wing without HLN and the red curve (s4.1g2m233a0p0.sect_forces) is the $c_{l}$ distribution for the cruise wing with HLN. The effects of the nacelles are clear with large slope changes at each nacelle location. The lift decrement is $\Delta C_{L}=0.09$ due to the presence of the HLN, and is obvious in figure 13 by the reduction in $c_{l}$ from the blue to the red curve, with the largest reduction occurring between $20<\mathrm{y}<180$. Figure 14 shows a comparison of the spanloading between the unblown high-lift wing with and without HLN for $\alpha=10^{\circ}$. The effect of HLN on the spanwise $c_{l}$ of the unblown high-lift wing is slightly smaller $\left(\Delta C_{L}=0.08\right)$ than the effect on spanwise $c_{l}$ for the cruise wing, and the reduction in $c_{l}$ is limited to $25<\mathrm{y}<170$.

The impacts of the high-lift nacelles on the $C_{L}$ of the blown, high-lift wing are shown in figure 15 for FUN3D with the BSL turbulence model. The nacelles reduce the lift curve slope and delays the stall angle of attack for the blown high-lift wing. The powered high-lift wing with high-lift nacelles (fig. 3(b)) has a decrement to lift of $\Delta C_{L}=-0.13$ at $\alpha=8^{\circ}$ to $\Delta C_{L}=-0.25$ at $\alpha=12^{\circ}$ compared to the powered high-lift wing without HLN (fig. 3(d)). Table 4 shows the component contributions to lift coefficient for the blown highlift wing with and without the HLN at $58 \mathrm{KTAS}$ and $\alpha=12^{\circ}$. The lift from the wing and flap for the high-lift wing without the HLN configuration is 0.349 higher than the configuration with HLN, but the contribution of the HLN (0.096) decreases the difference between the two configurations to $\Delta C_{L}=-0.25$. Figure 16 shows the comparison of pressure coefficient between the blown high-lift wing with and without HLN at a few 
span stations for $58 \mathrm{KTAS}$ and $\alpha=12^{\circ}$. Comparisons were made from $\mathrm{y}=0$ in. to $\mathrm{y}=180$ in. by 10 inch increments, and the comparisons with little difference in $C_{p}$ are not included, in particular inboard and outboard of the blown-flow region (downstream of the propeller slipstreams). There is more suction on the wing leading edge and on the upper flap surface for the blown, high-lift wing without HLN, than with HLN, as seen by the pressure coefficient comparisons for various stations in figure 16. Computational efforts are in progress to reduce the impacts of the nacelle pylon geometry on the wing lift and drag coefficients.

Figure 17 shows the effect of angle of attack on skin friction and lift coefficients for the blown high-lift wing without HLN at $58 \mathrm{KTAS}$ for solutions from FUN3D with the BSL turbulence model. The blown, high-lift wing ( $30^{\circ}$ flap configuration) without high-lift nacelles has $C_{L, \max }=4.642$ at $\alpha=12^{\circ}$ (fig. 15) and some flow separation inboard of the flap and outboard of the flap at the aileron (fig. 17(a)). The lift coefficient drops to the same value as the HLN configuration for $\alpha=13^{\circ}$ and $\alpha=14^{\circ}$ (fig. 15) when the inboard wing stalls (fig. 17(b)), and has a second drop in lift coefficient at $\alpha=15^{\circ}$ (fig. 15) when the outboard wing stalls (fig. 17(c)). Flow in the blown region of the wing (excluding the flap element) remains attached over the complete upper surface of the wing for both turbulence models over the range of angle of attack. Figure 18 further illustrates the changes in flow separation that occur with angle of attack by reviewing the impact on spanwise $c_{l}$ for the blown high-lift wing without HLN at 58 KTAS for FUN3D solutions with the BSL turbulence model. At $\alpha=12^{\circ}$ (blue line), there is some inboard and outboard flow separation and the $c_{l}$ is lower in these regions $(0<\mathrm{y}<20$ and $160<\mathrm{y}<180)$ than in the blown region $(24<$ $\mathrm{y}<160$ ). At $\alpha=13^{\circ}$ (red line), the $c_{l}$ within the unblown region of $0<\mathrm{y}<24$ and the blown region of $24<$ $\mathrm{y}<46$ drop substantially as the flow separation moves upstream toward the leading edge (fig. 17(b)). At $\alpha=$ $15^{\circ}$ (green line), the $c_{l}$ within the unblown region of $0<\mathrm{y}<24$ and the blown region of $24<\mathrm{y}<46$ drops even more than for $\alpha=13^{\circ}$, and the $c_{l}$ within the unblown region of $160<\mathrm{y}<180$ is now reduced as the outboard flow separation moves upstream toward the leading edge (fig. 17(c)).

\section{Conclusions}

The X-57 Maxwell was designed with a small, high aspect ratio cruise wing yielding a high cruise lift coefficient $\left(C_{L}=0.75\right)$ at $\alpha=0^{\circ}$. The cruise propulsors at the wingtip rotate counter to the wingtip vortex and reduce induced drag by 7.5 percent at $\alpha=0.6^{\circ}$. The unblown $C_{L, \max }$ of the high-lift wing is 2.439 . When the DEP system is operating at $164.4 \mathrm{hp}$ the conservative estimate of effective $C_{L, \max }$ is 4.202 at $\alpha=12^{\circ}$ with the blown, high-lift wing. A second, more aggressive estimate of effective $C_{L, \max }$ is 4.444 from the two-equation BSL turbulence model. Therefore, the conservative estimate of the lift augmentation from the high-lift, distributed electric propulsion system is 1.7 , calculated from the ratio of the DEP blown $C_{L, \max }=$ 4.202 to the unblown $C_{L, \max }=2.439$. The computational results from two different turbulence models exceed the goal of $C_{L, \max }=3.95$, and indicates that the stall speed goal can be met.

The CFD solutions were used to assess the computed drag versus the estimated drag needed to achieve the design cruise speed. The resulting computed wing drag coefficient of $C_{D}=0.02191$ is $\Delta C_{D}=0.00076$ above the estimated target wing drag coefficient of $C_{D}=0.02115$. However, the drag overage of $7.6 \mathrm{drag}$ counts is well under the included drag margin of 74.9 drag counts. Therefore, it is estimated that the design cruise goal should be achievable by only using about $10 \%$ of the originally planned drag margin.

The effect of the high-lift nacelles act to reduce lift coefficient by a maximum of 0.15 on the unblown cruise and high-lift wings, and reduce lift by 0.25 on the blown high-lift wing. 


\section{References}

1. "New Aviation Horizons Initiative and Complementary Investments," NP-2016-06-2167-HQ, NASA Headquarters.

2. Borer, Patterson, Viken, Moore, Clarke, Redifer, Christie, Stoll, Dubois, Bevirt, Gibson, Foster, Osterkamp: "Design and Performance of the NASA SCEPTOR Distributed Electric Propulsion Flight Demonstrator," Aviation Forum in Washington D. C., AIAA 2016-3920, 13-17 June 2016.

3. Biedron, R. T., Carlson, J. R.; Derlaga, J. M.; Gnoffo, P. A.; Hammond, D. P.; Jones, W. T.; Kleb, B.; Lee-Rausch, E. M.; Nielsen, E. J.; Park, M. A.; Rumsey, C. L.; Thomas, J. L.; and Wood, W. A.: "FUN3D Manual: 13.0," NASA TM-2016-219330.

4. Frink, N. T.: "Tetrahedral Unstructured Navier-Stokes Method for Turbulent Flow," AIAA Journal, Vol. 36, No. 11, Nov. 1998, pp. 1975-1982.

5. Frink, N. T., Pirzadeh, S. Z., Parikh, P. C., Pandya, M. J., and Bhat, M. K.: "The NASA Tetrahedral Unstructured Software System," The Aeronautical Journal, Vol. 104, No. 1040, October 2000, pp. 491499.

6. Deere, K. A., Viken, S. A., Carter, M. B., Viken, J. K., Derlaga, J. M., Stoll, A. M.: “Comparison of High-Fidelity Computational Tools for Wing Design of a Distributed Electric Propulsion Aircraft," Aviation Forum, AIAA, Denver, Colorado, 5-9 June 2017.

7. Shur, M. L., Strelets, M. K., Travin, A. K., Spalart, P. R.: “Turbulence Modeling in Rotating and Curved Channels: Assessing the Spalart-Shur Correction,” AIAA Journal Vol. 38, No. 5, 2000, pp. 784 792.

8. Spalart, P. R.: "Strategies for Turbulence Modeling and Simulation," International Journal of Heat and Fluid Flow, Vol. 21, 2000, pp. 252-263.

9. Menter, F. R.: "Two-Equation Eddy-Viscosity Turbulence Models for Engineering Applications," AIAA Journal, Vol. 32, No. 8, August 1994, pp. 1598-1605.

10. Drela, M., and Youngren, H.: XROTOR Download Page, http://web.mit.edu/drela/Public/web/xrotor/, accessed 6 May 2014.

11. Langtry, R. B., and Menter, F. R.: "Correlation-Based Transition Modeling for Unstructured Parallelized Computational Fluid Dynamics Codes,” AIAA Journal, Vol. 47, No. 12, Dec. 2009 , pp. 2894-2906.

12. Menter, F. R., Langtry, R., Likki, S., Suzen, Y., Huang, P., and Volker, S.: “A Correlation-based Transition Model Using Local Variables - Part I: Model Formulation,” Journal of Turbomachinery, Vol. 128, No. 3, pp. 413-422, 2006.

13. Pirzadeh, S.: "Advanced Unstructured Grid Generation for Complex Aerodynamics Applications," AIAA 2008-7178, 26 ${ }^{\text {th }}$ AIAA Applied Aerodynamics Conference, August 2008.

14. Pirzadeh, S.: "Three-dimensional unstructured Viscous Grids by the Advancing-Layers Method," AIAA Journal, Vol. 34, No. 1, January 1996, pp. 43-49.

15. " $2^{\text {nd }}$ AIAA CFD High Lift Prediction Workshop Gridding Guidelines," http://hiliftpw.larc.nasa.gov, https://hiliftpw.larc.nasa.gov/Workshop2/GriddingGuidelines-HiLiftPW2-v2.pdf, March 2013.

16. Frink, N. T., Tormalm, M., Schmidt, S.: "Unstructured CFD Aerodynamic Analysis of a Generic UCAV Configuration," paper nbr 25, RTO-MP-AVT-170, NATO OTAN.

17. Goldstein, S.: "On the Vortex Theory of Screw Propellers," Proceeding of the Royal Society of London A: Mathematical, Physical and Engineering Sciences, vol. 792, no. 123, Apr. 1929, pp. 440-465.

18. Stern, F.; Kim, H. T.; and Patel, V. C.: "A Viscous-Flow Approach to the Computation of PropellerHull Interaction,” Journal of Ship Research, vol. 32, no. 4, Dec. 1988, pp. 246-262.

19. Langtry, R.B., Menter, F.R., Likki, S.R., Suzen, Y.B., Huang, P.G., and Völker, S.: "A Correlation based Transition Model using Local Variables Part 2 - Test Cases and Industrial Applications”, ASMEGT2004-53454, ASME TURBO EXPO 2004, Vienna, Austria.

20. Langtry, R.B., and Menter, F.R.: "Transition Modeling for General CFD Applications in Aeronautics", AIAA paper 2005-522, 2005. 
Denver, CO

Table 1. The X-57 Maxwell sizing study drag component breakdown and resulting required aircraft drag coefficient.

\begin{tabular}{|c|c|c|}
\hline Total Airplane Drag for Mod IV & Force - Newtons & Force - lb \\
\hline Margin & 133 & 29.9 \\
\hline Interference & 10.8 & 2.43 \\
\hline Induced & 165 & 37.09 \\
\hline Wing Friction & 65.7 & 14.77 \\
\hline Wing Profile & 28.2 & 6.34 \\
\hline Tail Friction & 33.7 & 7.58 \\
\hline Tail Profile & 5.69 & 1.28 \\
\hline High-Lift Nacelles & 83.1 & 18.68 \\
\hline Cruise Nacelles & 33.6 & 7.5 \\
\hline Fuselage & 404 & 90.82 \\
\hline Total & 962.79 & 216.44 \\
\hline \multirow[t]{2}{*}{ ESTIMATED AIRPLANE } & DRAG COEFFICIENT & 0.05423 \\
\hline & MARGIN & 0.00749 \\
\hline$C_{D}$ & $=\mathbf{D} /(\mathbf{q} * \mathbf{S})$ & $=\mathrm{D} /\left(\mathbf{0 . 5} * \rho * \mathrm{~V}^{2} * \mathrm{~S}\right)$ \\
\hline$\rho$ at $8,000 \mathrm{ft}$ & 0.00187 & slugs $/ \mathbf{f t}^{3}$ \\
\hline $\mathbf{V}$ & 150 & KTAS \\
\hline $\mathbf{V}$ & 253.17 & $\mathbf{f t} / \mathbf{s}$ \\
\hline $\mathbf{S}$ & 66.67 & $\mathbf{f t}^{2}$ \\
\hline $\mathbf{q}$ & 59.87 & $\mathbf{l b} / \mathbf{f t}^{2}$ \\
\hline
\end{tabular}


Table 2. The X-57 Maxwell sizing study estimate of wing drag buildup.

\begin{tabular}{|c|c|c|}
\hline & Force - Newtons & Force - lb \\
\hline Induced & 165 & 37.09 \\
\hline Wing Friction & 65.7 & 14.77 \\
\hline Wing Profile & 28.2 & 6.34 \\
\hline Cruise Nacelles & 33.6 & 7.55 \\
\hline Subtotal (no HLN) & & 65.76 \\
\hline High-Lift Nacelles & 83.1 & 18.68 \\
\hline Subtotal (with HLN) & & 84.44 \\
\hline ESTIMATED WING & DRAG COEFFICIENT with HLN & 0.02115 \\
\hline$C_{D}$ & $=\mathbf{D} /(\mathbf{q} * \mathbf{S})=\mathbf{D} /\left(\mathbf{0 . 5} \rho * \mathbf{V}^{2} * \mathbf{S}\right)$ & \\
\hline$\rho$ at $8,000 \mathrm{ft}$ & 0.00187 & slugs $/ \mathbf{f t}^{3}$ \\
\hline $\mathbf{V}$ & 150 & KTAS \\
\hline $\mathbf{V}$ & 253.17 & $\mathbf{f t} / \mathbf{s}$ \\
\hline $\mathbf{S}$ & 66.67 & $\mathbf{f t}^{2}$ \\
\hline $\mathbf{q}$ & 59.87 & $\mathbf{l b} / \mathbf{f t}^{2}$ \\
\hline
\end{tabular}

Table 3. The drag coefficients for separate components from fully turbulent and transitional flow solutions of FUN3D and USM3D at unpowered cruise, at $R e=2.83$ million, $150 \mathrm{KTAS}$, $\alpha=0.6^{\circ}$.

\begin{tabular}{|l|l|l|l|l|l|l|}
\hline & $\boldsymbol{C}_{\boldsymbol{D}, \text { total }}$ & $\boldsymbol{C}_{\boldsymbol{D}, \text { wing }}$ & $\boldsymbol{C}_{\boldsymbol{D}, \boldsymbol{T N}}$ & $\boldsymbol{C}_{\boldsymbol{D}, \boldsymbol{H L N}}$ & $\boldsymbol{C}_{\boldsymbol{D}, \boldsymbol{p y l o n s}}$ & $\boldsymbol{\Delta}_{\boldsymbol{D}, \boldsymbol{w i n g}}$ \\
\hline FUN3D SST & 0.03282 & 0.02538 & 0.00489 & 0.00270 & -0.00015 & \\
\hline FUN3D SARC+QCR & 0.03254 & 0.02496 & 0.00506 & 0.00256 & -0.00004 & \\
\hline USM3D SA & 0.03349 & 0.02637 & 0.00558 & 0.00177 & -0.00023 & \\
\hline USM3D SST & 0.03557 & 0.02750 & 0.00539 & 0.00284 & -0.00017 & \\
\hline USM3D LM Transition & 0.02938 & 0.02353 & 0.00545 & 0.00077 & -0.00038 & -0.00397 \\
\hline
\end{tabular}

Table 4. The comparison of component contributions to lift coefficient for the high-lift wing with and without HLN, FUN3D BSL, at $R e=1.33$ million, $58 \mathrm{KTAS}, \alpha=12^{\circ}$.

\begin{tabular}{|c|c|c|c|c|c|c|}
\hline Configuration & $\boldsymbol{C}_{\boldsymbol{L}, \boldsymbol{e} f \boldsymbol{f}}$ & $\boldsymbol{C}_{\boldsymbol{L}, \boldsymbol{w i n g}}$ & $\boldsymbol{C}_{\boldsymbol{L}, \text { flap }}$ & $\boldsymbol{C}_{\boldsymbol{L}, \boldsymbol{T N}}$ & $\boldsymbol{C}_{\boldsymbol{L}, \boldsymbol{H L N}}$ & $\boldsymbol{C}_{\boldsymbol{L}, \boldsymbol{p r o p s}}$ \\
\hline with HLN & 4.410 & 3.517 & 0.404 & 0.061 & 0.096 & 0.331 \\
\hline without HLN & 4.664 & 3.818 & 0.452 & 0.063 & 0.000 & 0.331 \\
\hline
\end{tabular}


Denver, CO

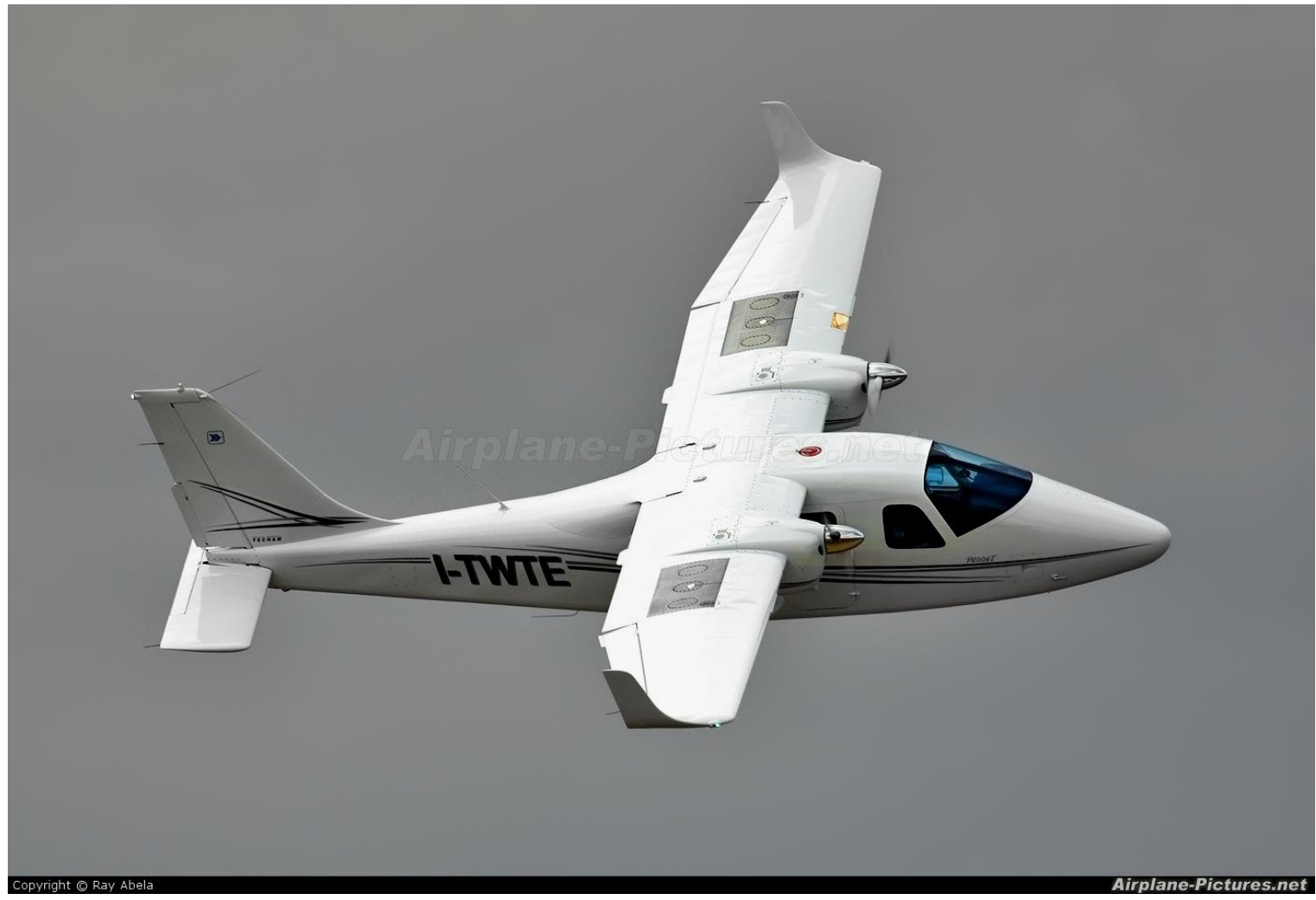

Figure 1. The original Tecnam P2006T aircraft.

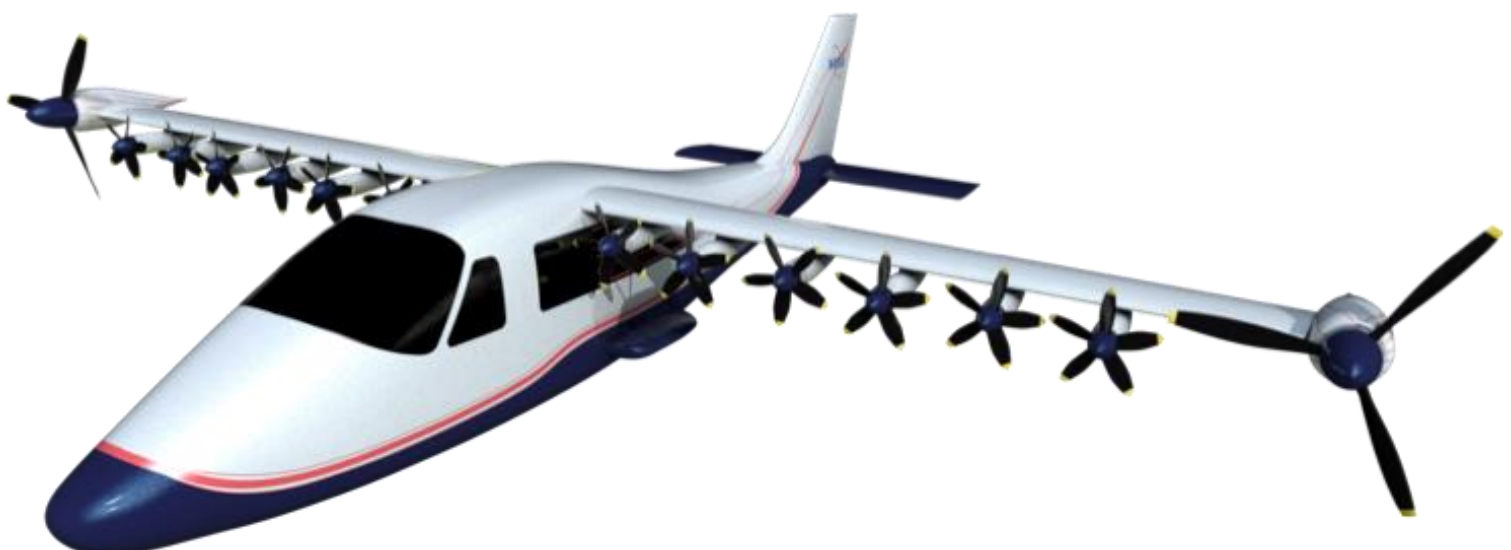

Figure 2. The X-57 Maxwell DEP aircraft. The Tecnam P2006T fuselage and tail with the DEP wing system that includes the wingtip propulsors and the DEP high-lift motors. 
Denver, CO

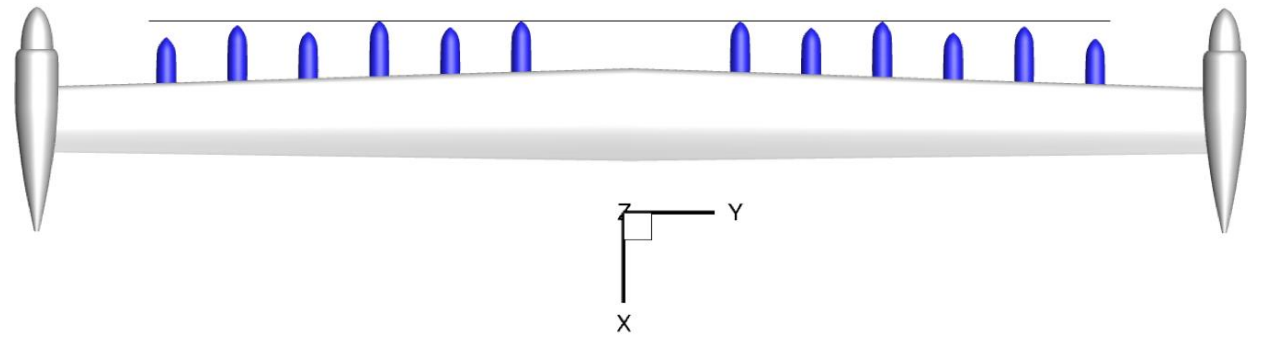

(a) Cruise wing with tip nacelles, HLN (blue), and black alignment line to emphasize the staggered pattern of the HLN.

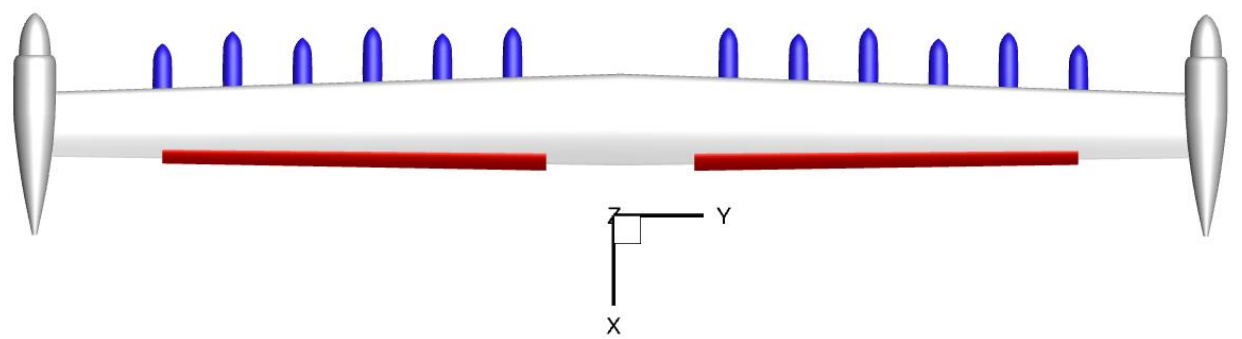

(b) High-lift wing with tip nacelles, $30^{\circ}$ flap (red), and HLN (blue).

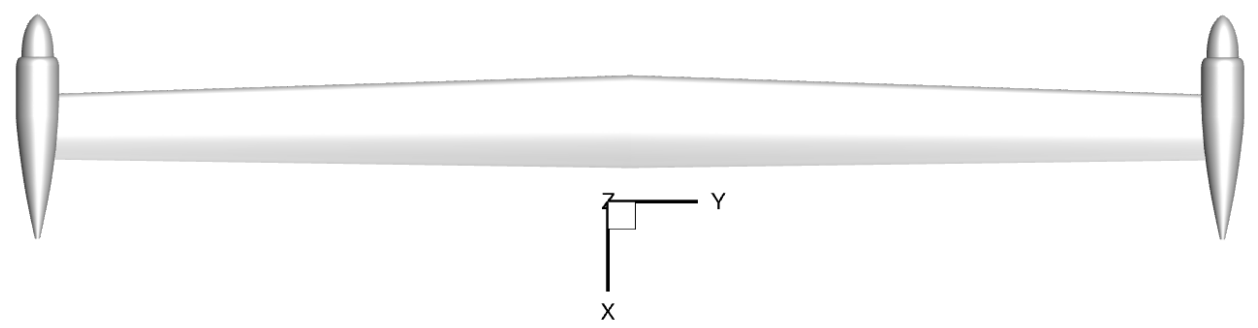

(c) Cruise wing with tip nacelles, no HLN.

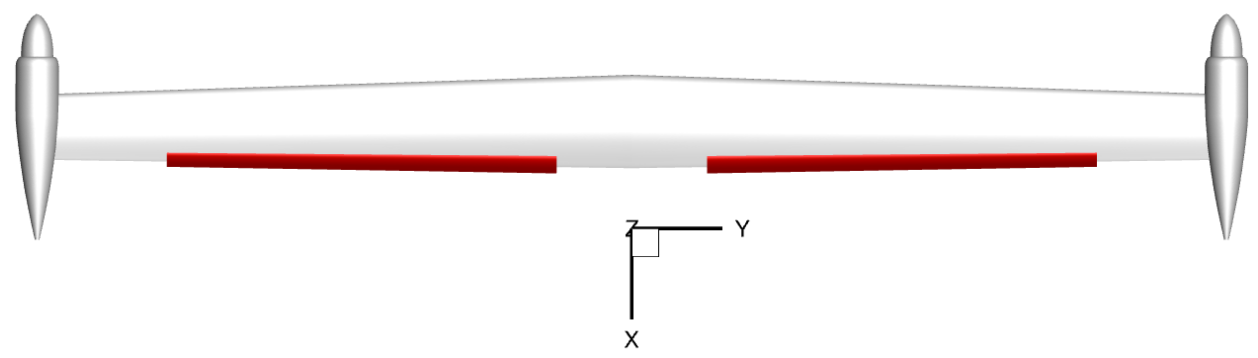

(d) High-lift wing with tip nacelles and $30^{\circ}$ flap (red), no HLN.

Figure 3. The wing configurations for CFD analysis of the X-57 Maxwell airplane. 
Denver, CO

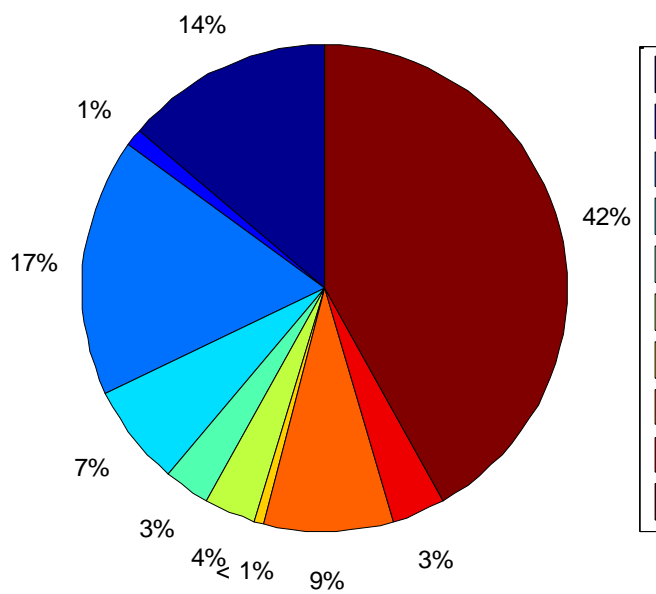

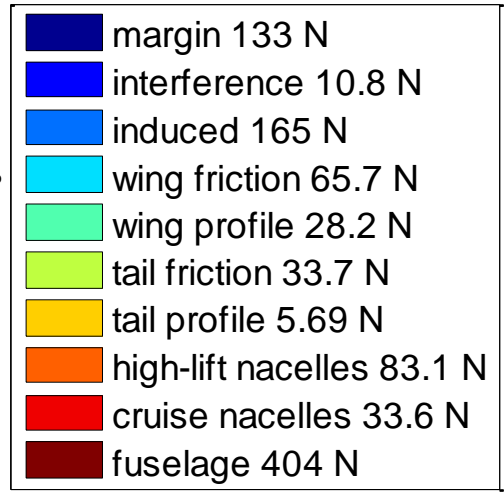

Figure 4. The X-57 Maxwell aircraft sizing study drag component breakdown.

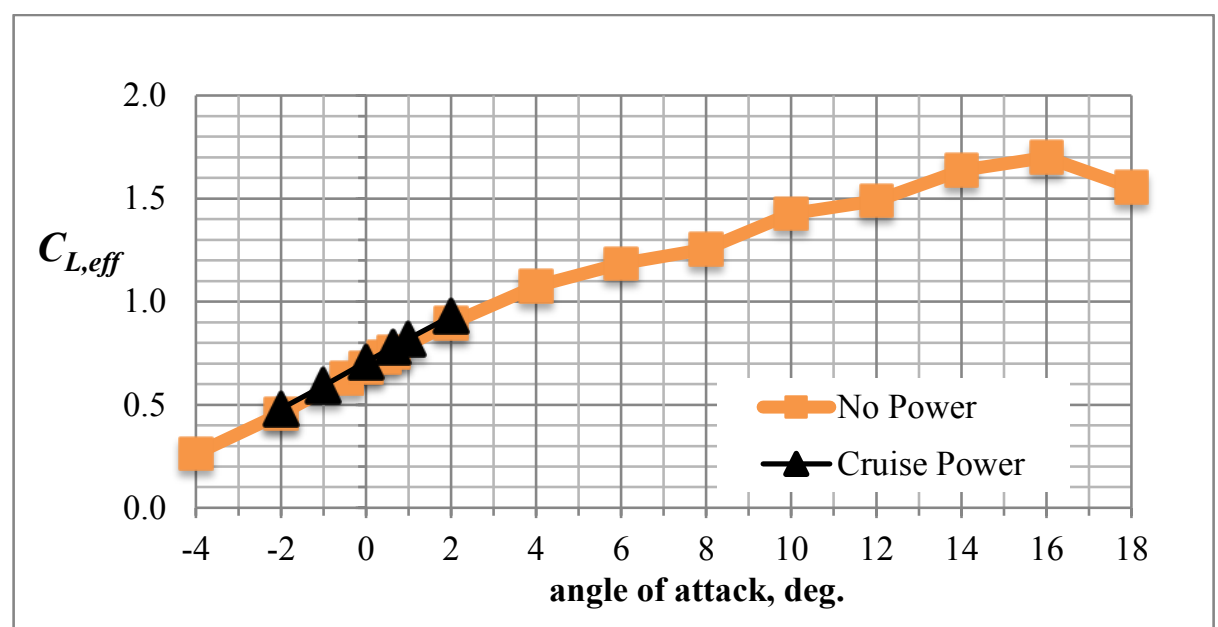

(a) Effective Lift Coefficient

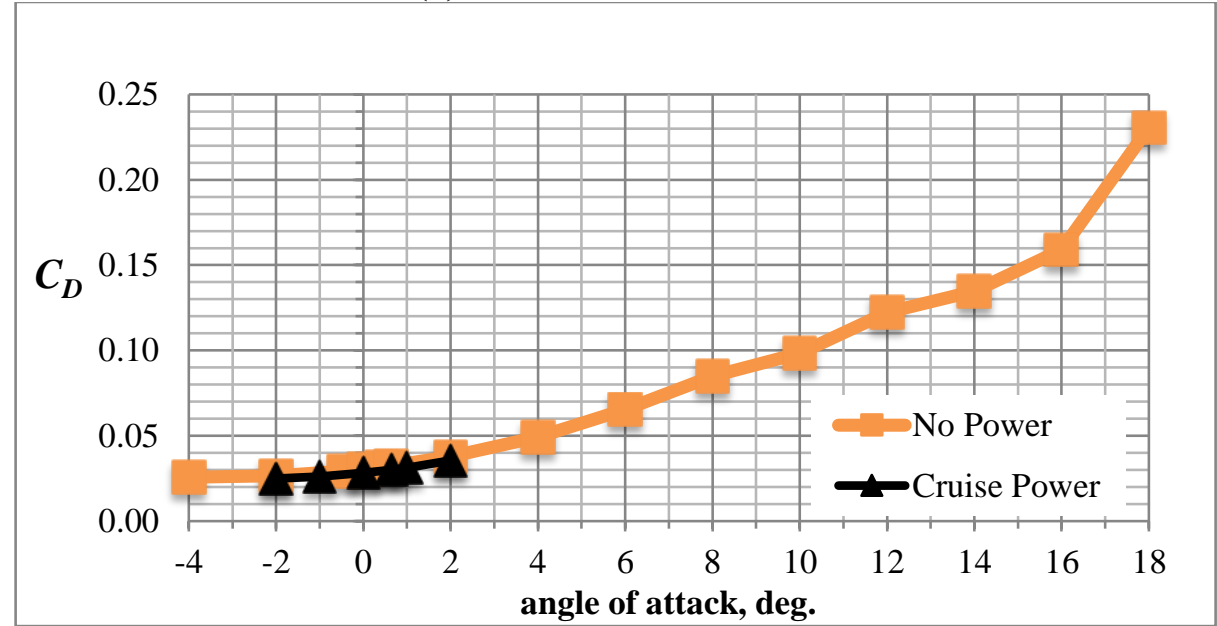

(b) Drag Coefficient

Figure 5. The lift and drag coefficient for the cruise wing with high-lift and wingtip nacelles, $150 \mathrm{KTAS}, M=0.233, R e=2.83$ million, $\mathrm{h}=8000 \mathrm{ft}$, and $\mathrm{T}=30.5^{\circ} \mathrm{F}$. Cruise power propeller conditions of 2250 RPM, $117.38 \mathrm{hp}$, and total thrust of $230 \mathrm{lbf}$. FUN3D SARC+QCR. 
Denver, CO

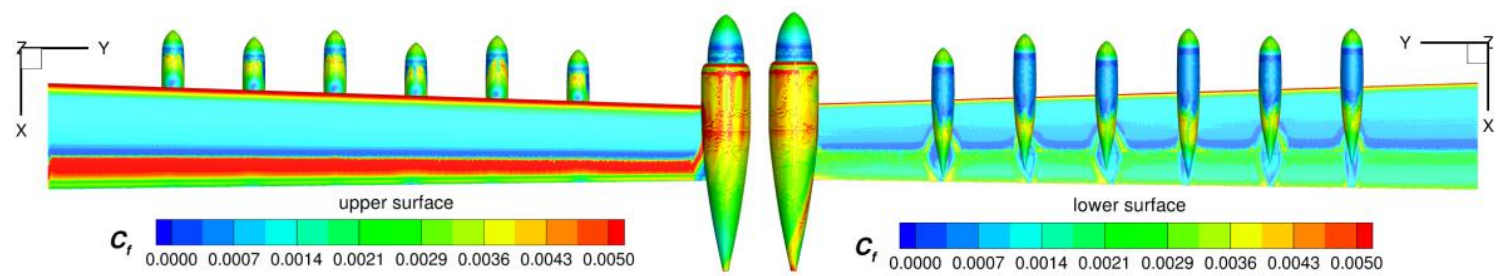

(a) USM3D LM

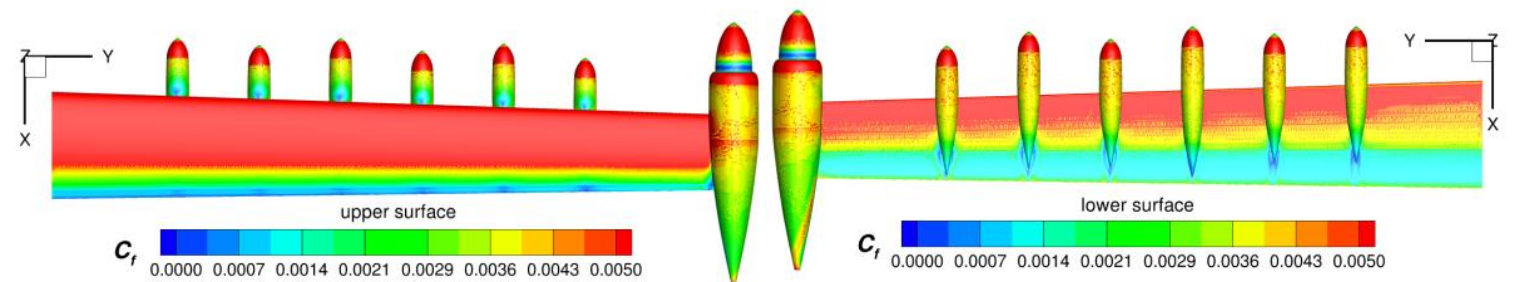

(b) USM3D SST

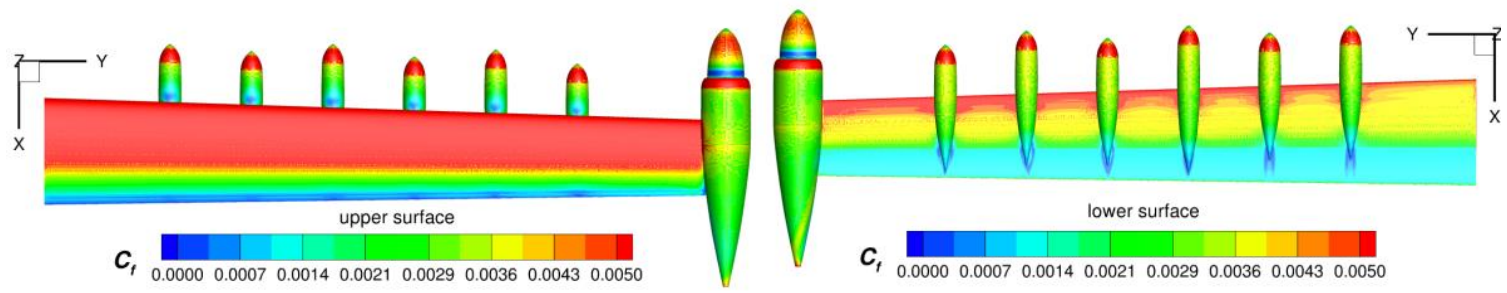

(c) USM3D SA

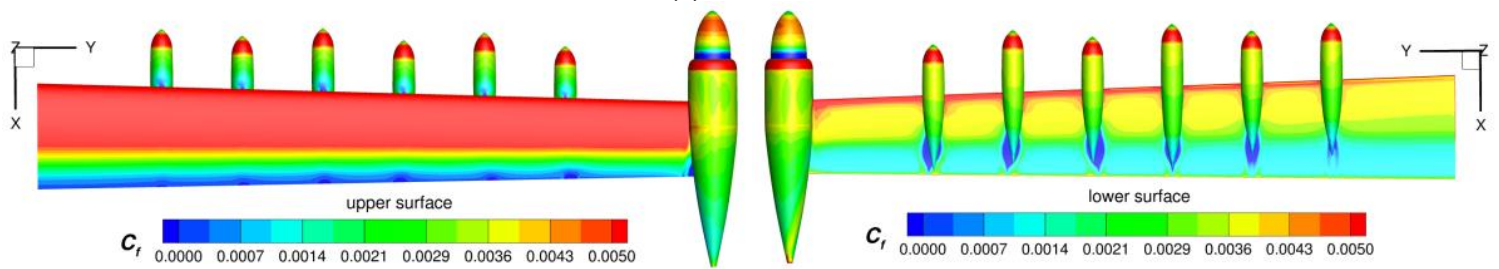

(d) FUN3D SST

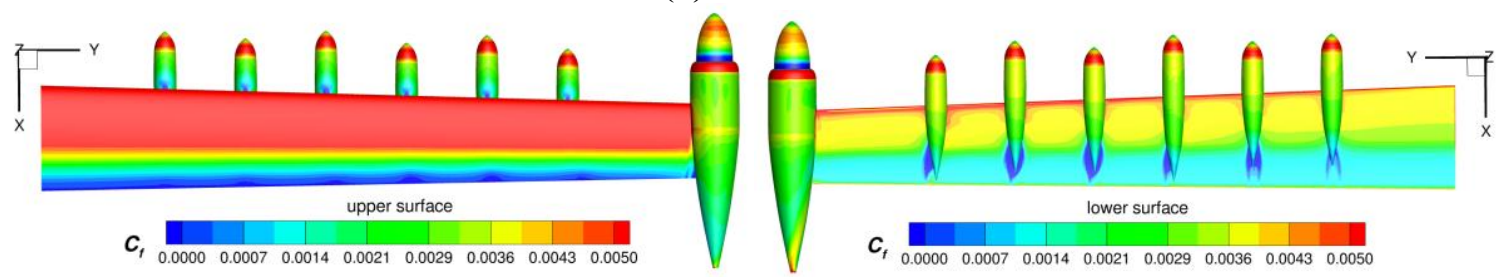

(e) FUN3D SARC+QCR

Figure 6. The comparison of skin friction coefficient between transitional flow (LM) and fully turbulent flow (SST, SA, SARC+QCR) on the unpowered cruise wing with high-lift and wingtip nacelles at $150 \mathrm{KTAS}, M=0.233, R e=2.83$ million, $\mathrm{h}=8000 \mathrm{ft}, \mathrm{T}=30.5^{\circ} \mathrm{F}$, and $\alpha=0.6^{\circ}$. 


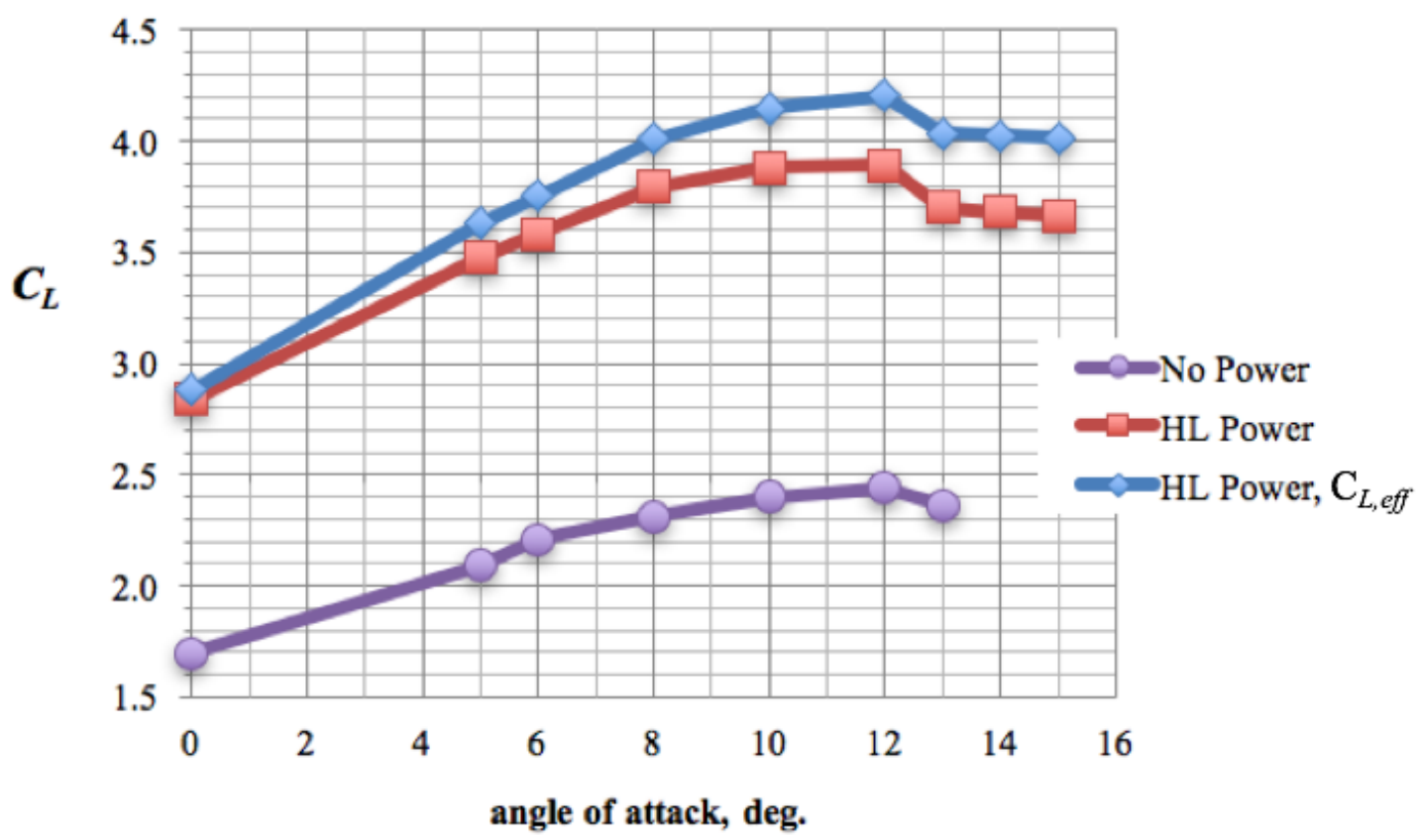

Figure 7. The lift coefficient for the high-lift wing with high-lift and wingtip nacelles, 58 KTAS, $M=0.0878, R e=1.33$ million, $h=0 \mathrm{ft}$, and $T=59^{\circ} \mathrm{F}$. Blown, high-lift wing power conditions of $4548 \mathrm{RPM}, 164.4 \mathrm{hp}(13.7 \mathrm{hp} / \mathrm{prop})$, and total thrust of $596.4 \mathrm{lbf}$. FUN3D SARC+QCR.

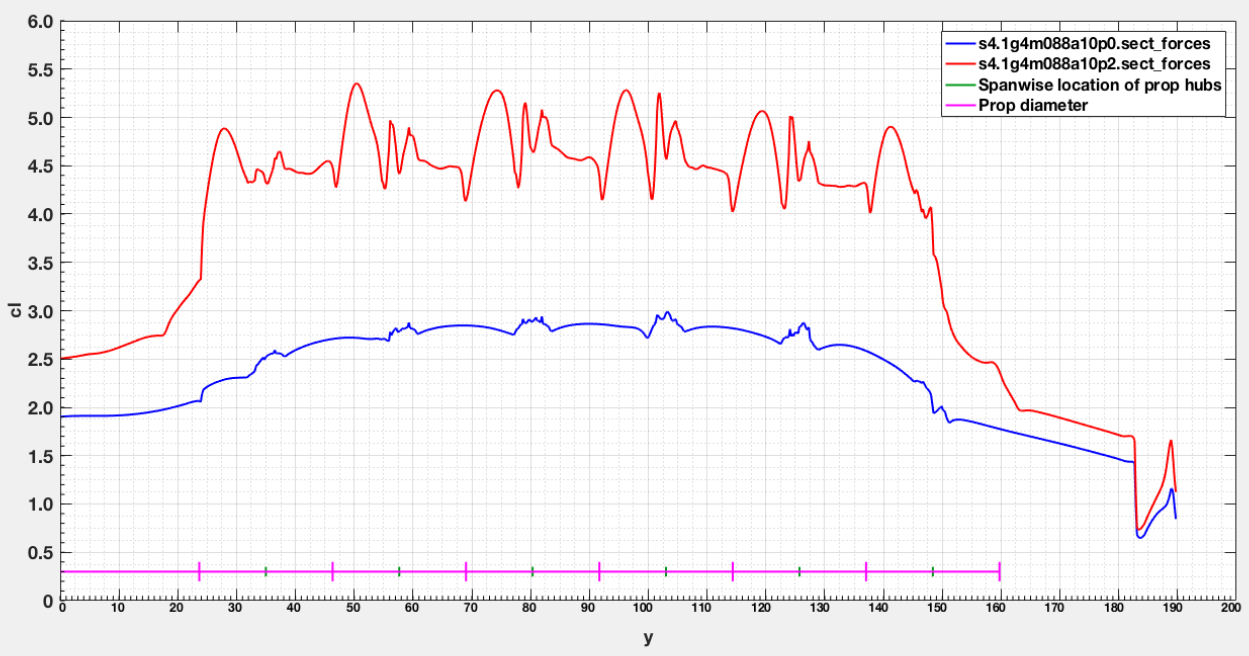

Figure 8. The sectional lift coefficient for the unblown (blue) and the blown (red) high-lift wing with high-lift and wingtip nacelles, $58 \mathrm{KTAS}, M=0.0878, \mathrm{Re}=1.33 \mathrm{million}, \mathrm{h}=0 \mathrm{ft}$, and $\mathrm{T}=59^{\circ} \mathrm{F}$. Blown, high-lift wing power conditions of $4548 \mathrm{RPM}, 164.4 \mathrm{hp}(13.7 \mathrm{hp} / \mathrm{prop})$, and total thrust of 596.4 lbf. FUN3D SARC+QCR. 


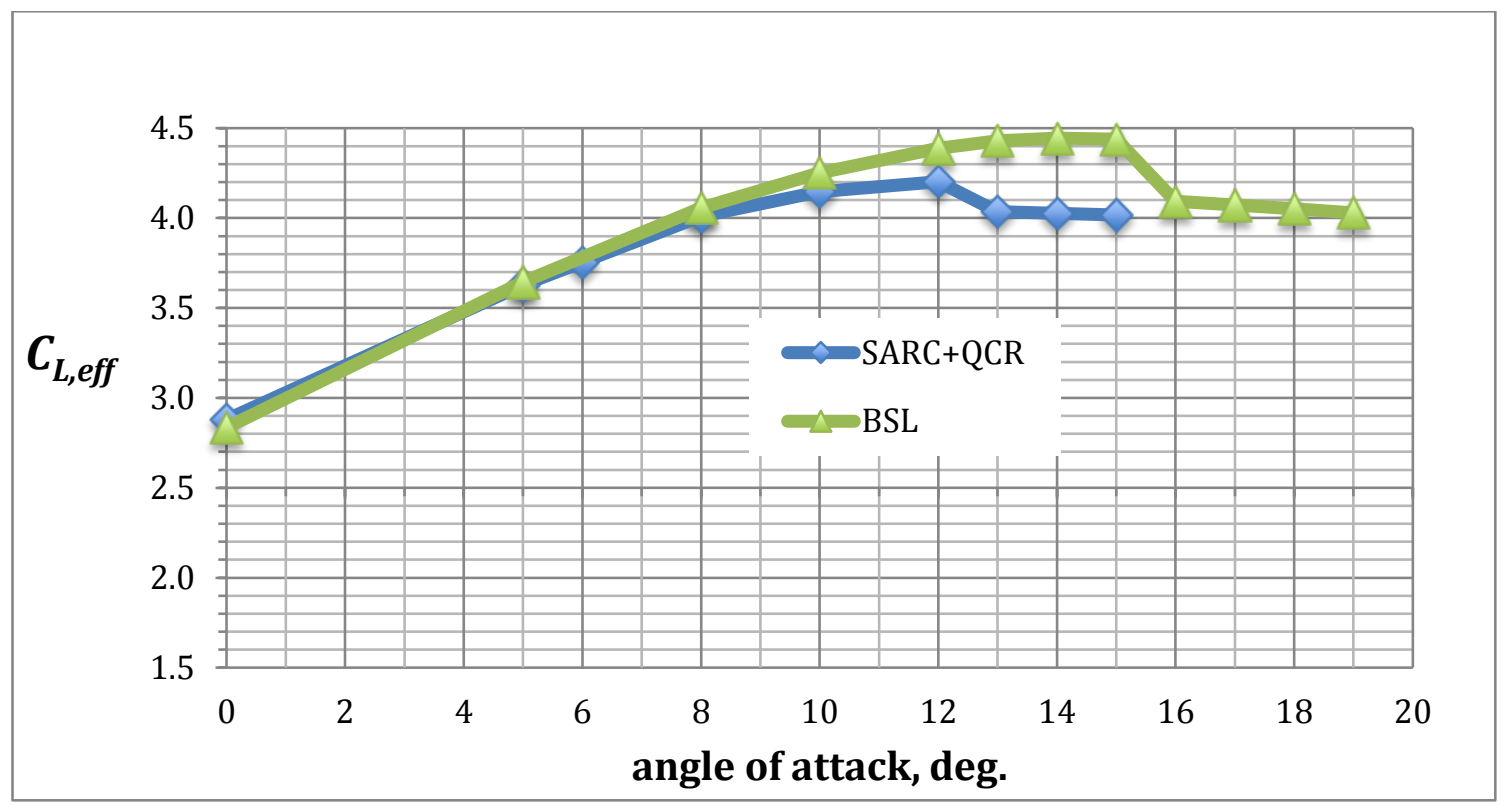

Figure 9. The comparison of effective lift coefficient between FUN3D turbulence models for the blown, high-lift wing, with high-lift and wingtip nacelles, $58 \mathrm{KTAS}, M=0.0878, \mathrm{Re}=1.33$ million, $h=0 \mathrm{ft}$, and $\mathrm{T}=59^{\circ} \mathrm{F}$. Blown, high-lift wing power conditions of $4548 \mathrm{RPM}, 164.4 \mathrm{hp}$ (13.7 hp/prop), and total thrust of $596.4 \mathrm{lbf}$.

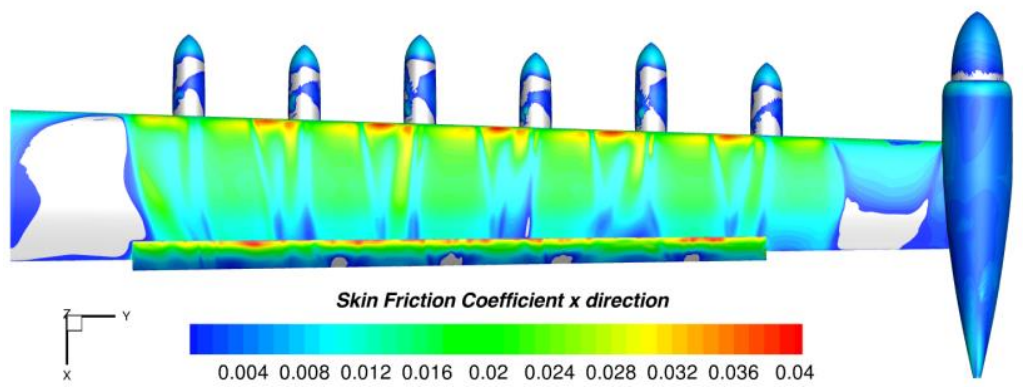

(a) SARC+QCR turbulence model, $\alpha=13^{\circ}$

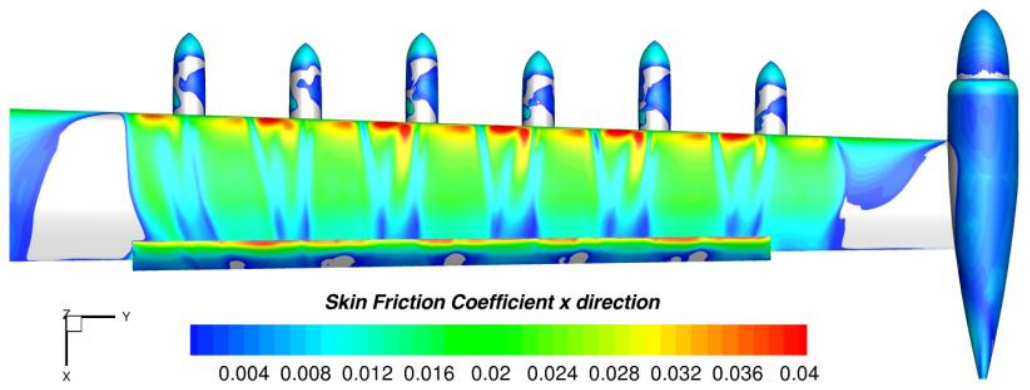

(b) BSL turbulence model, $\alpha=16^{\circ}$

Figure 10. The skin friction coefficient from FUN3D for the blown, high-lift wing with wingtip nacelles and $\mathrm{HLN}, 58 \mathrm{KTAS}, M=0.0878, \mathrm{Re}=1.33$ million, $\mathrm{h}=\mathbf{0} \mathrm{ft}$, and $\mathrm{T}=59^{\circ} \mathrm{F}$. Blown, high-lift wing power conditions of $4548 \mathrm{RPM}, 164.4 \mathrm{hp}$ (13.7 hp/prop), and total thrust of 596.4 lbf. 


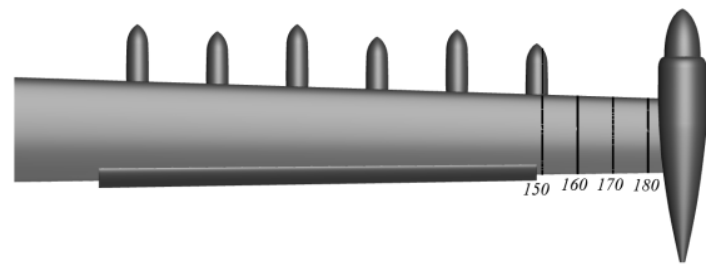

(a) Span locations $y=150$ in. to $y=180$ in.

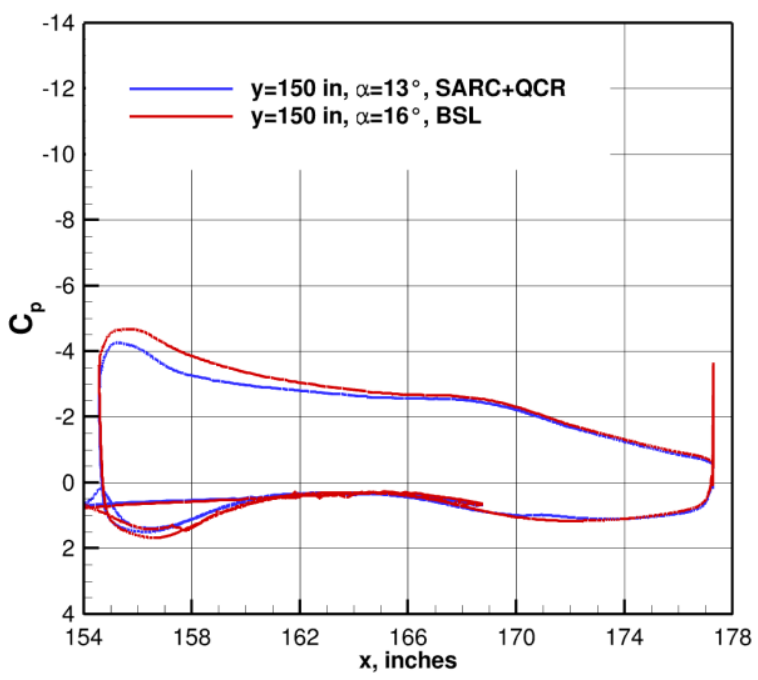

(b) $y=150$ in.

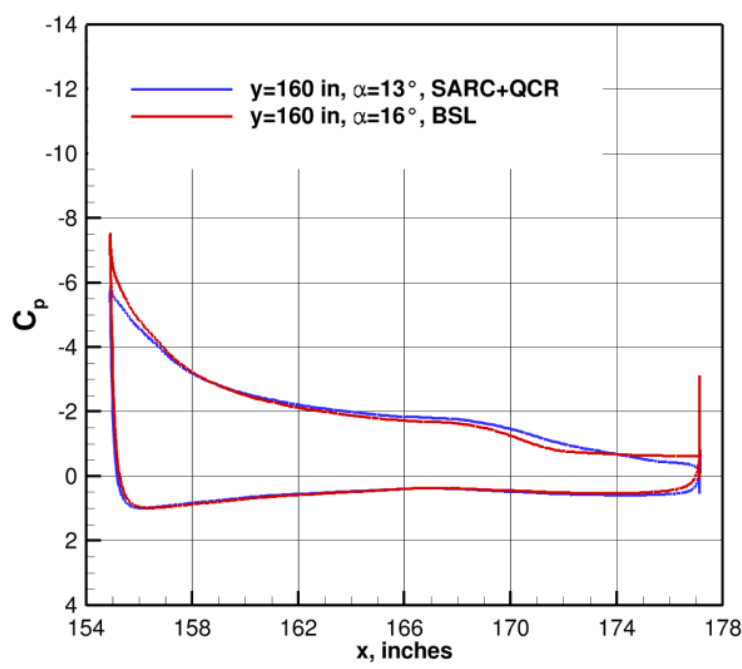

(c) $y=160$ in.

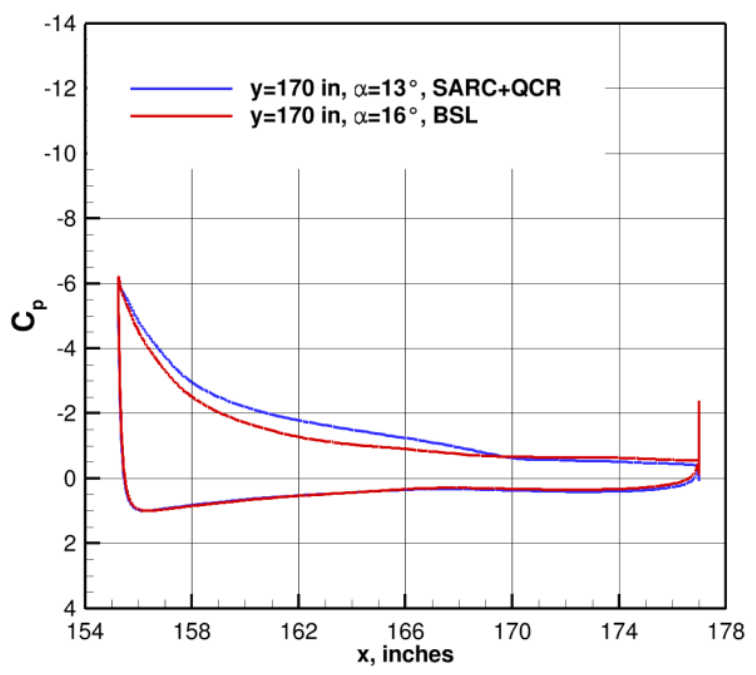

(d) $\mathbf{y}=\mathbf{1 7 0}$ in.

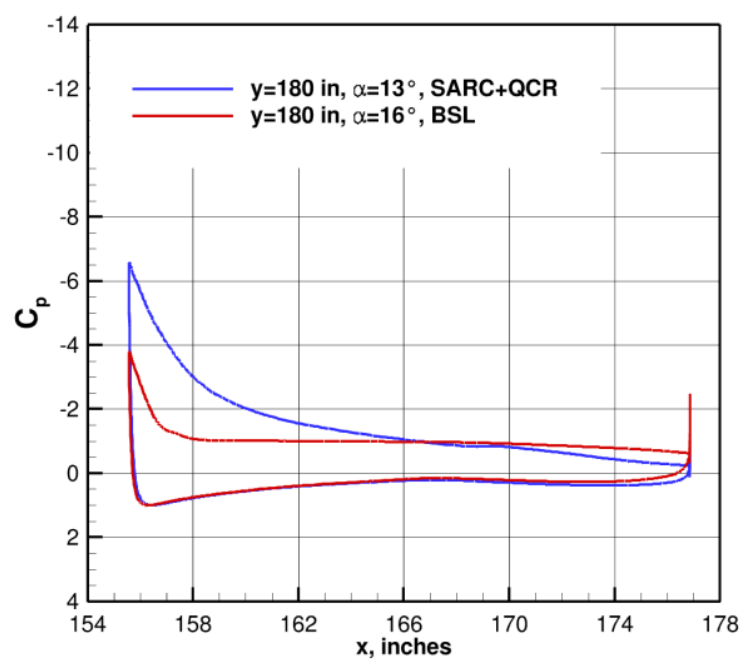

(e) $\mathbf{y}=\mathbf{1 8 0}$ in.

Figure 11. The comparison of pressure coefficient between solutions at the $C_{L}$ break $\alpha$ for FUN3D solutions with SARC+QCR $\left(\alpha=13^{\circ}\right)$ and BSL $\left(\alpha=16^{\circ}\right)$ at outboard span stations for the blown, high-lift wing, wingtip nacelles and high-lift nacelles at $58 \mathrm{KTAS}, \mathrm{T}=59^{\circ} \mathrm{F}, \mathrm{h}=0 \mathrm{ft}$, and $R e=1.33$ million. Blown, high-lift wing power conditions of $4548 \mathrm{RPM}, 164.4 \mathrm{hp}$ (13.7 hp/prop), and total thrust of $596.4 \mathrm{lbf}$. 
Denver, CO

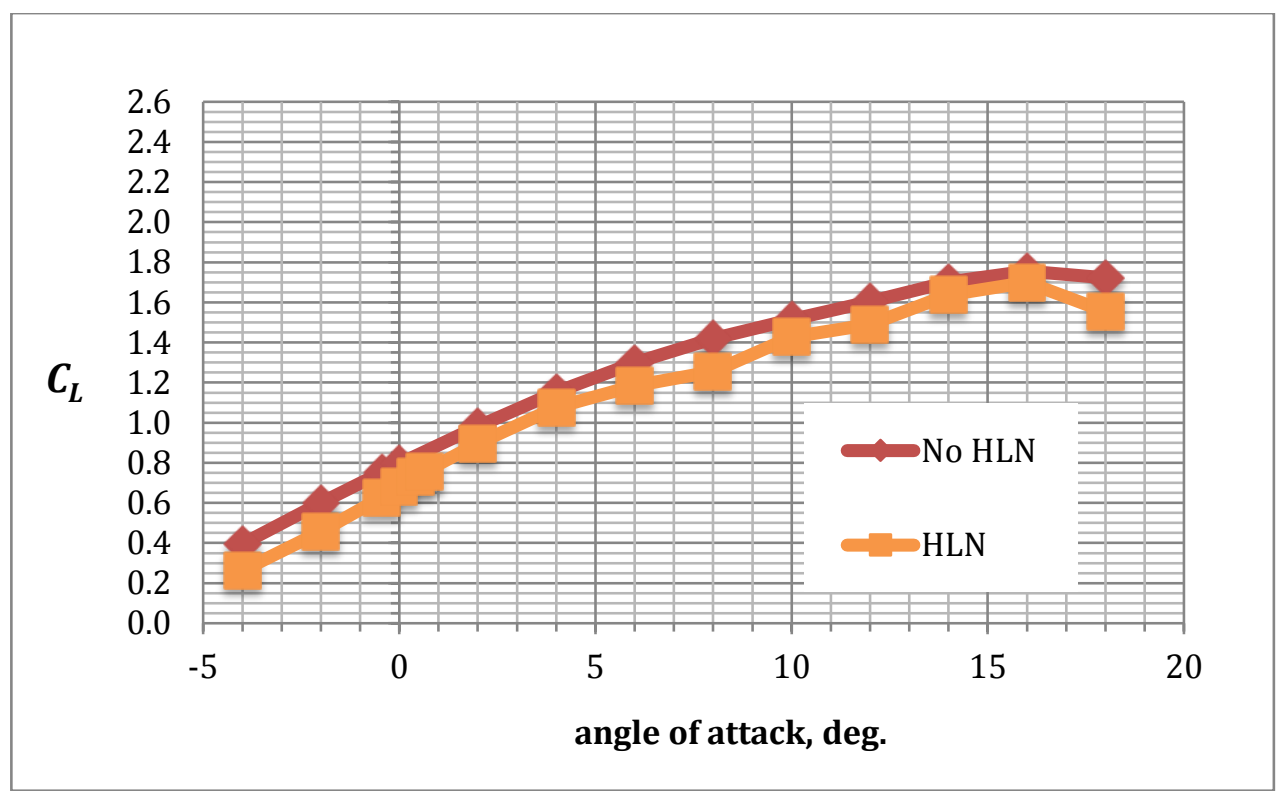

(a) Cruise wing at $150 \mathrm{KTAS}, \mathrm{Re}=\mathbf{2 . 8 3}$ million, $\mathrm{h}=\mathbf{8 0 0 0} \mathrm{ft}, \mathrm{T}=30.5^{\circ} \mathrm{F}$

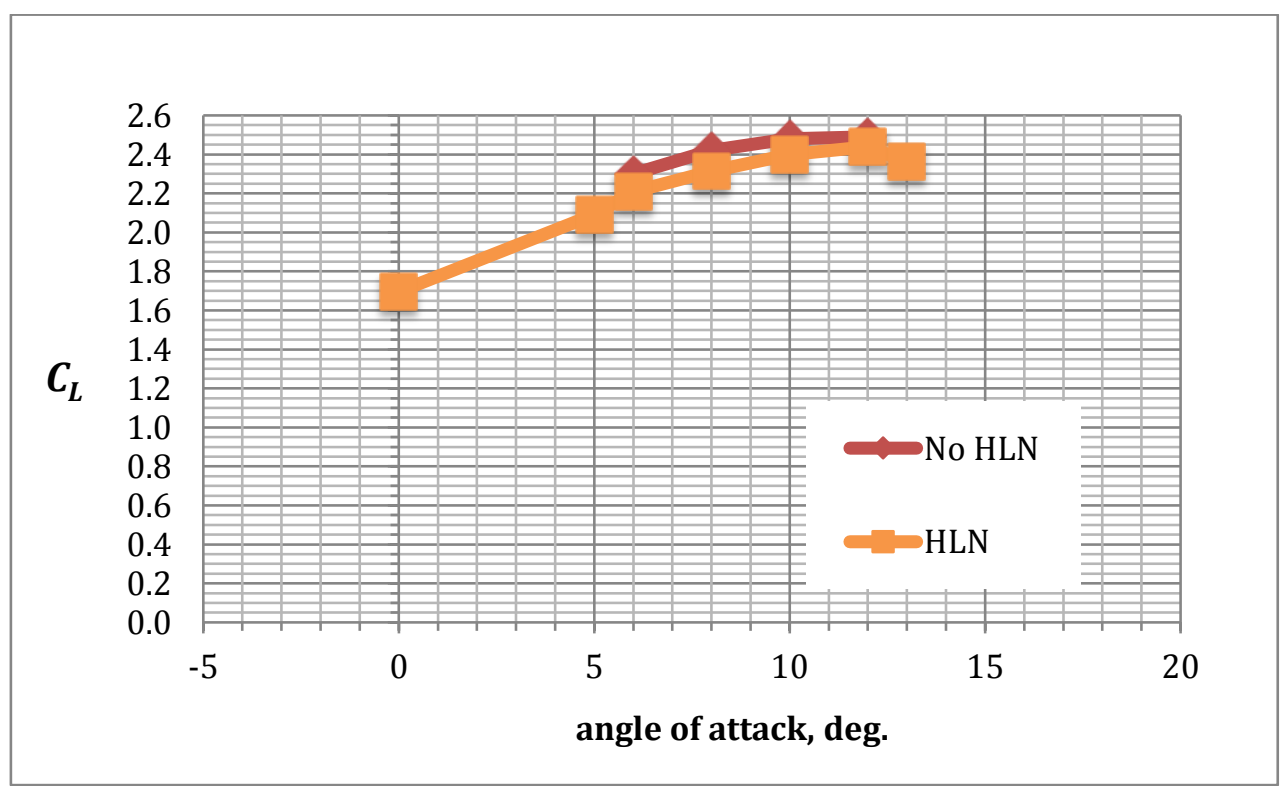

(b) $30^{\circ}$ flap configuration at $58 \mathrm{KTAS}, \mathrm{Re}=1.33$ million, $\mathrm{h}=0 \mathrm{ft}, \mathrm{T}=59^{\circ} \mathrm{F}$

Figure 12. The impact of the high-lift nacelles on lift coefficient for the unblown wing, FUN3D SARC+QCR. 
Denver, CO

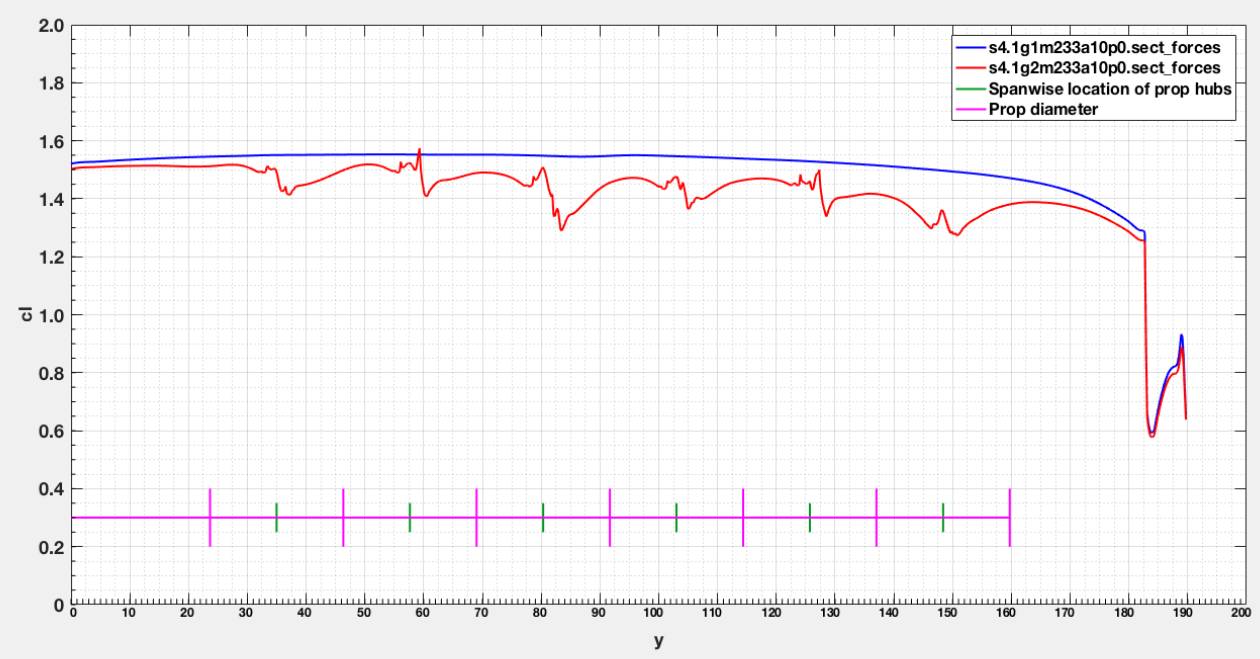

Figure 13. The impact of the high-lift nacelles on the sectional lift coefficient for the unblown cruise wing, at $150 \mathrm{KTAS}, \alpha=10^{\circ}, \mathrm{Re}=2.83$ million, $h=8000 \mathrm{ft}$, and $\mathrm{T}=30.5^{\circ} \mathrm{F}$. FUN3D

SARC+QCR. (Blue, without HLN; Red, with HLN)

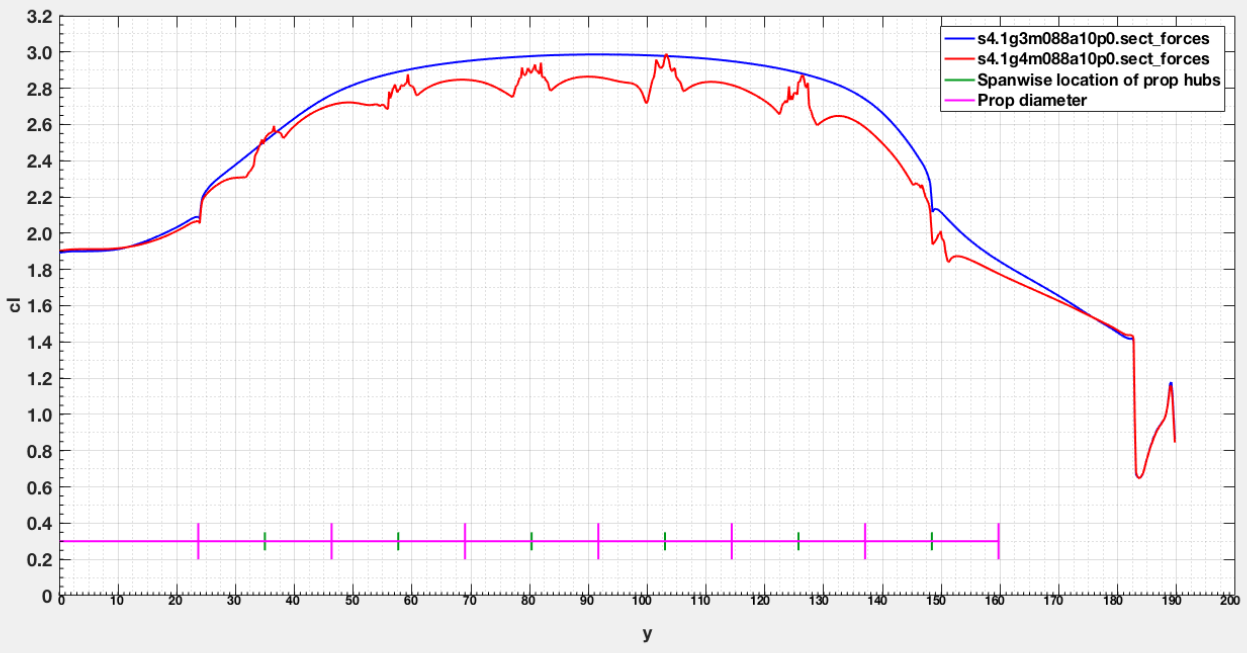

Figure 14. The impact of the high-lift nacelles on sectional lift coefficient for the unblown highlift wing $\left(30^{\circ}\right.$ flap), at $58 \mathrm{KTAS}, \alpha=10^{\circ}, \mathrm{Re}=1.33$ million, $\mathrm{h}=0 \mathrm{ft}$, and $\mathrm{T}=59^{\circ} \mathrm{F}$. FUN3D

SARC+QCR. (Blue, without HLN; Red, with HLN) 


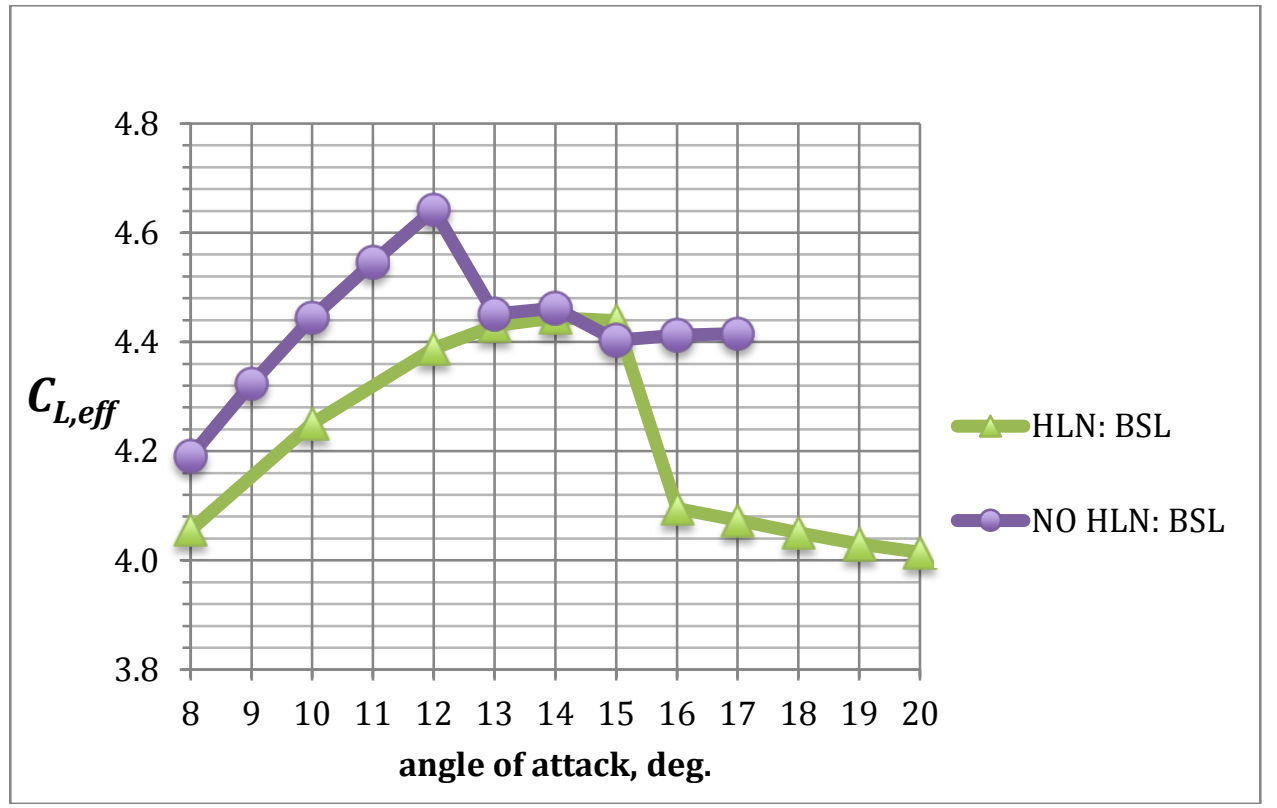

Figure 15. The impact of the high-lift nacelles on effective lift coefficient from FUN3D at 58 KTAS, $R e=1.33$ million, for the blown, high-lift wing with power conditions of 4548 RPM, $164.4 \mathrm{hp} \mathrm{(13.7} \mathrm{hp/prop),} \mathrm{and} \mathrm{total} \mathrm{thrust} \mathrm{of} 596.4 \mathrm{lbf}$.

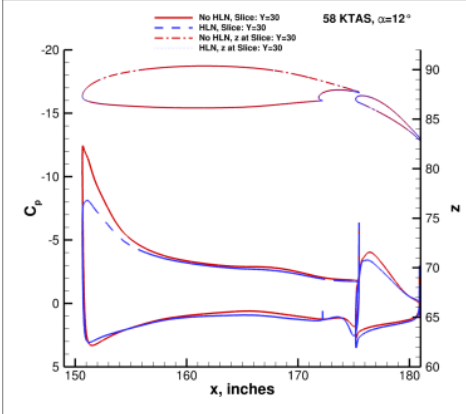

(a) $\mathbf{y}=\mathbf{3 0}$ in.

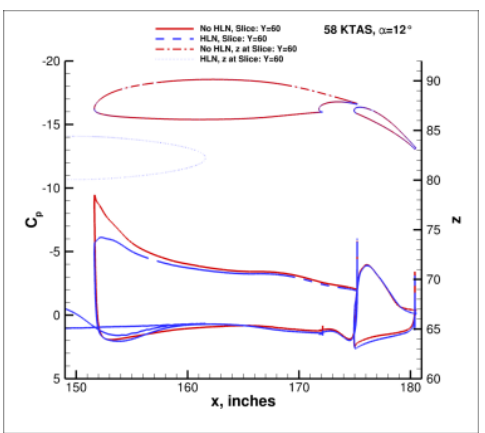

(b) $y=60$ in.

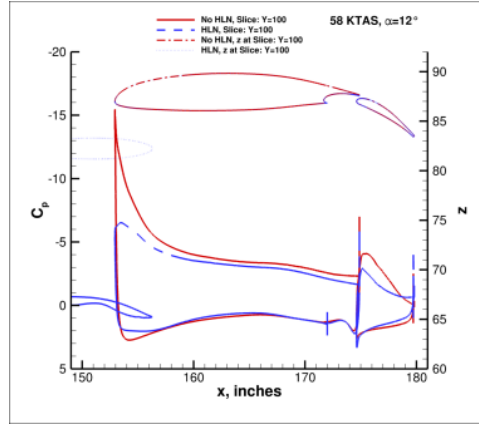

(c) $\quad y=100$ in.

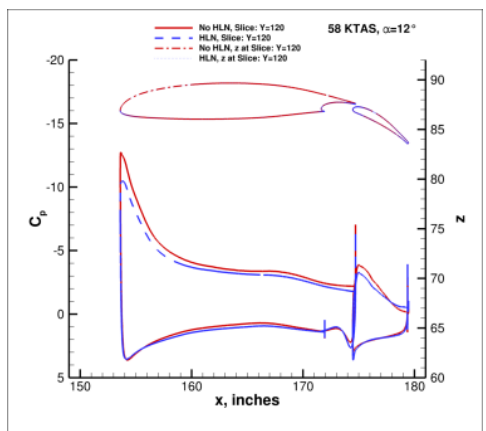

(d) $\quad \mathbf{y}=\mathbf{1 2 0}$ in.

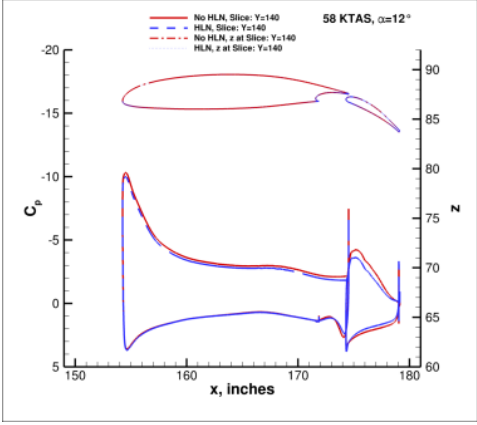

(e) $\quad \mathbf{y}=\mathbf{1 4 0}$ in.

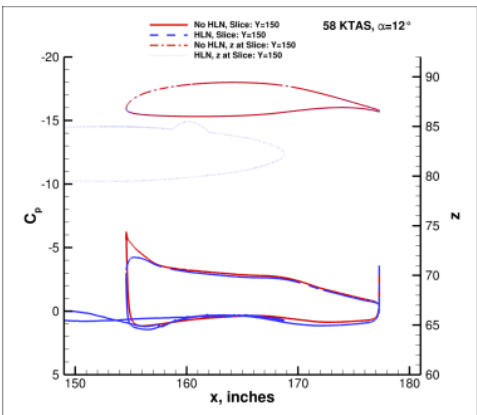

(f) $\quad y=150$ in.

Figure 16. The comparison of pressure coefficient between the blown, high-lift wing with and without high-lift nacelles, FUN3D BSL, $58 \mathrm{KTAS}, \mathrm{Re}=1.33$ million, $\alpha=12^{\circ}$. 
Denver, CO

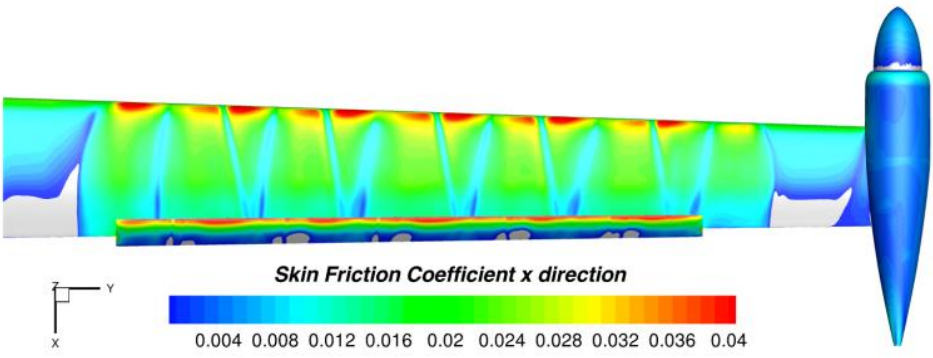

(a) $\alpha=12^{\circ}, C_{L, \text { eff }}=4.642$

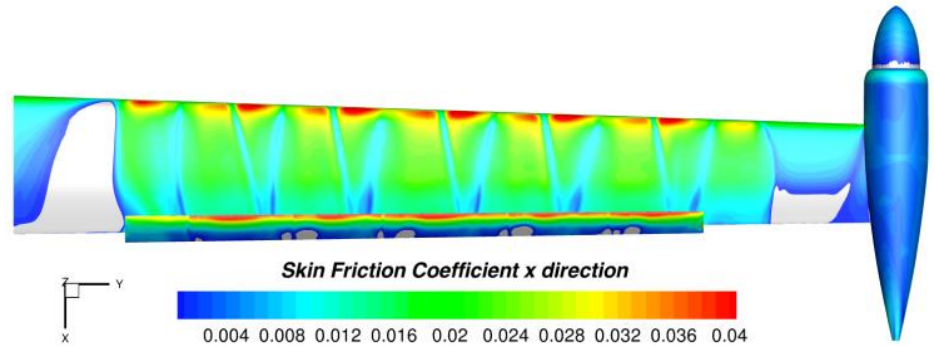

(b) $\alpha=13^{\circ}, C_{L, \text { eff }}=4.451$

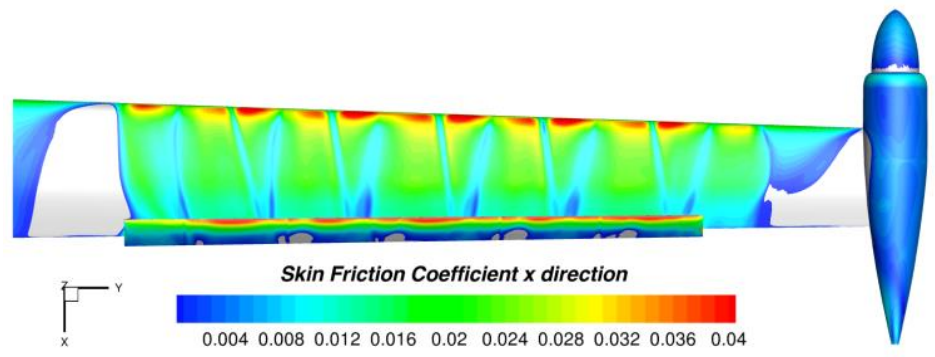

(c) $\alpha=15^{\circ}, C_{L, \text { eff }}=4.403$

Figure 17. The effect of angle of attack on skin friction and lift coefficients from FUN3D BSL for the blown, high-lift wing without high-lift nacelles at $58 \mathrm{KTAS}, \mathrm{Re}=1.33$ million and power conditions of $4548 \mathrm{RPM}, 164.4 \mathrm{hp}(13.7 \mathrm{hp} / \mathrm{prop})$, and total thrust of $596.4 \mathrm{lbf}$.

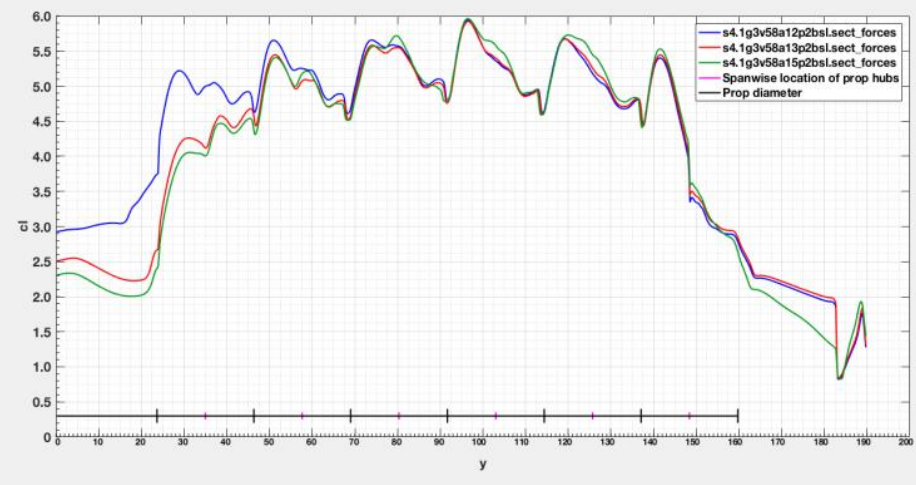

Figure 18. The spanwise sectional lift coefficient from FUN3D BSL for the blown, high-lift wing without high-lift nacelles for $\alpha=12^{\circ}$ (blue), $\alpha=13^{\circ}$ (red), and $\alpha=15^{\circ}$ (green) at 58 KTAS, Re=1.33 million and power conditions of $4548 \mathrm{RPM}, 164.4 \mathrm{hp}$ (13.7 hp/prop), and total thrust of $596.4 \mathrm{lbf}$. 